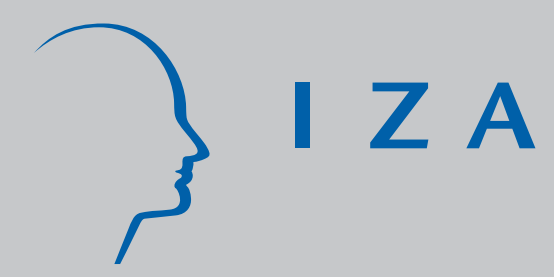

IZADP No. 2066

The Caring Hand that Cripples:

The East German Labor Market After Reunification (Detailed Version)

Dennis J. Snower

Christian Merkl

April 2006 


\title{
The Caring Hand that Cripples: The East German Labor Market After Reunification (Detailed Version)
}

\author{
Dennis J. Snower \\ Kiel Institute for the World Economy, \\ University of Kiel, CEPR and IZA Bonn \\ Christian Merkl \\ Kiel Institute for the World Economy \\ and University of Kiel
}

Discussion Paper No. 2066

April 2006

IZA

P.O. Box 7240

53072 Bonn

Germany

Phone: +49-228-3894-0

Fax: +49-228-3894-180

Email: iza@iza.org

Any opinions expressed here are those of the author(s) and not those of the institute. Research disseminated by IZA may include views on policy, but the institute itself takes no institutional policy positions.

The Institute for the Study of Labor (IZA) in Bonn is a local and virtual international research center and a place of communication between science, politics and business. IZA is an independent nonprofit company supported by Deutsche Post World Net. The center is associated with the University of Bonn and offers a stimulating research environment through its research networks, research support, and visitors and doctoral programs. IZA engages in (i) original and internationally competitive research in all fields of labor economics, (ii) development of policy concepts, and (iii) dissemination of research results and concepts to the interested public.

IZA Discussion Papers often represent preliminary work and are circulated to encourage discussion. Citation of such a paper should account for its provisional character. A revised version may be available directly from the author. 
IZA Discussion Paper No. 2066

April 2006

\section{ABSTRACT}

\section{The Caring Hand that Cripples: The East German Labor Market After Reunification (Detailed Version)}

The East German labor market has hardly made any progress since German reunification, despite massive migration flows and support from the West. We argue that East Germany is in trouble precisely because of the support it has received. This paper explores the phenomenon of "the caring hand that cripples," arising from bargaining by proxy, the adoption of the West German welfare system and the associated employment persistence. Even the steady decrease of labor cost (normalized by productivity) since the beginning of the nineties did not help to kick start the East. We suggest that labor force participants fell into "traps," concerning low skills, ageing of the workforce, labor-saving capital and skills, capital underutilization, and unemployment arising from the decline of the tradable sector.

JEL Classification: $\quad$ E24, J3, P2

Keywords: German unification, labor markets, labor market traps

Corresponding author:

Dennis Snower

The Kiel Institute for the World Economy

Düsternbrooker Weg 120

24105 Kiel

Germany

Email: dennis.snower@ifw-kiel.de

\footnotetext{
*We are indebted to Olivier Blanchard, Alfred Boss, Alessio Brown, Gerd Hansen, Gernot Klepper, Henning Klodt, Gerald Krause, Rolf J. Langhammer, Thomas Lontzek, Frank Oskamp, and other IfW researchers for valuable comments. We thank Mariana Heinrich, Gert Pönitzsch, and Ellen Schmieder for extremely helpful research assistance.
} 


\section{Introduction ${ }^{1}$}

The East German labor market has made disappointing progress since German reunification. The unemployment rate almost doubled from 1991 to 2004 (from around $10 \%$ to $20 \%)^{2}$, despite massive migration flows from East Germany to West Germany. The official figures depict only the tip of the iceberg, since they neglect the big stock of hidden unemployment (e.g. Holger Bonin and Klaus Zimmermann, 2000, Johann Fuchs and Brigitte Weber, 2005). The share of long-term unemployed has climbed from a quarter in 1992 to almost a half in 2004 (e.g. Sachverständigenrat, 2004, p. 315). Since 1997 the East German GDP has grown at rates similar or even lower than those in the West. ${ }^{3}$

This sorry performance may seem puzzling, for East Germans were the envy of their newly-capitalist neighbors. Through reunification, they received well-functioning legal and welfare systems, an orderly privatization process, generous welfare benefits and infrastructure investment - all financed by transfers from West Germany.

At the beginning of the nineties this jump start helped East Germany to have a much smoother transition in terms of macroeconomic stability than its Eastern European neighbors (see Appendix for a comparison to Czech Republic). But after an initial straw fire, spurred by West Germany, the Eastern neighbors started to catchup or even to overhaul. They are doing much better in terms of their unemployment rates. ${ }^{4}$ Slovenia is the first transition country which has a bigger GDP per head than East Germany. Others are probably going to follow soon.

Today, transfers are running at around $€ 80$ billion per year ${ }^{5}$ (about $4 \%$ of Germany's GDP) with no sign of abating; $50 \%$ of them constitutes social assistance, e.g. unemployment and retirement benefits. About one quarter of East German private consumption is paid by West German transfers. When the transfer driven production is deducted, even in East Germany's economically strong regions the GDP per head is only about $55 \%$ of the West German level (Harald Lehmann et al., 2005). Never before has a region received such immense support in the move to capitalism; but the fledgling has not thrived. What went wrong?

The answer, we will argue, is that the East German labor market is in trouble precisely because of the support it has received. This paper explores the phenomenon

\footnotetext{
${ }^{1}$ We are indebted to Olivier Blanchard, Alfred Boss, Alessio Brown, Gerd Hansen, Gernot Klepper, Henning Klodt, Gerald Krause, Rolf J. Langhammer, Thomas Lontzek, Frank Oskamp, and other IfW researchers for valuable comments. We thank Mariana Heinrich, Gert Pönitzsch, and Ellen Schmieder for extremely helpful research assistance.

${ }^{2}$ According to the official statistics of the Bundesagentur für Arbeit (2006) the unemployment rate among dependent employed in East Germany (including Berlin) has risen from 10.2\% in 1991 to $20.1 \%$ in 2004 .

${ }^{3}$ Source: Statistische Ämter des Bundes und der Länder (2005).

${ }^{4}$ The International Labour Organization (2004, p. 27) writes that the average unemployment rate in the transition economies is $9.2 \%$.

${ }^{5}$ Numbers for 2003. Gross transfers (not deducting federal taxes) even amounted to 116 billion Euro (Joachim Ragnitz, 2003, p. 2).
} 
of "the helping hand that cripples." We view East Germany as an important case study in the pitfalls to transition, highlighting weaknesses of other European welfare systems.

We argue that the following mistakes were made in East Germany, each disguised as social support.

Bargaining by proxy: Right after reunification, East German wage bargaining was primarily in the hands of West German unions and employers, rather than their weak and inexperienced Eastern counterparts (e.g. Hans-Werner Sinn, 2002). The Westerners rapidly raised the Eastern wage, in the name of solidarity and equality with the Easterners. In reality, however, Western unions feared migration of workers from East to West and of firms in the opposite direction, resulting in downward pressure on Western wages and employment. Given a low short-run elasticity of labor demand, there was an incentive to raise East German wages.

Unemployment benefits and associated welfare entitlements: Through reunification, the East inherited generous unemployment support. This, along with stringent job security provisions and other labor market regulations, also put upward pressure on wages and kept them high (relative to productivity) even once East Germans began to gain control over their own wages. ${ }^{6}$

The post-unification wage hike led to a sharp fall in East German employment. Thereafter, however, Eastern real wages fell relative to productivity. But the employment rate scarcely rose. Why?

Employment persistence: Through reunification East Germany inherited West German labor legislation, including generous job security provisions that raised firing costs and labor regulations that raised hiring costs. Due to these "caring hand" measures, employment became much more persistent (temporary labor market shocks had more persistent after-effects).

Yet employment persistence cannot tell the whole story. It explains why the employment response was sluggish, but not why the Eastern employment rate hardly rose at all. Moreover, East German industrial labor productivity remains about one quarter beneath that in the West even though capital intensity is higher than in the West (e.g. Henning Klodt, 2000).

We will suggest that these phenomena may have arisen because East German labor force participants fell into "traps," concerning low skills, ageing of the workforce, labor-saving capital and skills, capital underutilization, and unemployment arising from the decline of the tradeable sector. These traps were all promoted by the "caring hand" of the West.

\footnotetext{
${ }^{6}$ Other factors also helped make labor expensive in the East. For instance, the huge investment subsidies after reunification naturally raised the price of labor relative to the price of capital. The decision to adopt a 1-to-1 exchange rate between the East and West German mark after reunification, amounted to a massive appreciation of the EG currency. Yet we will focus on bargaining by proxy, unemployment benefits, job security and regulations, for without them, EG wages could have compensated for the investment subsidies and the exchange rate decision.
} 
We maintain that the problems above extend well beyond East Germany; rather, they appear whenever labor market institutions generate substantial labor turnover costs and permit insiders to exert significant market power in wage determination. Bargaining by proxy is widespread: within firms, insiders (whether formally through unions or through informal understandings) often have an influence on the wages of entrants. Employment persistence arises whenever there are costs of adjusting employment, the labor force, or the size of the insider workforces within firms. The traps are well-known to policy makers everywhere, especially in terms of their consequences (e.g. poverty traps, unemployment traps, low-skill traps). The existence of traps constitute an important reason why labor market reforms often need to be deep (large changes in policy instruments) and broad (involving several complementary measures).

In what follows, Section 2 presents a model of wage determination and employment persistence, Section 3 deals with the traps, Section 4 presents our calibration exercises, and Section 5 concludes.

\section{Wage Determination and Employment Persis- tence}

We present a particularly simple model of the East German labor market, with the following sequence of decisions: first, wages are determined, taking into account their influence on migration and employment; second, migration decisions are made, taking wages as given; and third, firms make their employment decisions, taking wages and migration as given. We start with the last stage.

\subsection{Employment}

Assume constant returns to labor and let $a$ and $\widehat{a}$ be labor productivity in East Germany and West Germany, ${ }^{7}$ respectively. (All West German variables are denoted by ${ }^{\wedge}$.) There is a random operating $\operatorname{cost} \varepsilon_{t},{ }^{8}$ iid across workers and time, with a mean normalized to zero and a constant cumulative distribution $\Gamma\left(\varepsilon_{t}\right)$. For the wage $w$, firing cost $f$ per worker (constant), firing rate $\phi$, and discount factor $\delta$, an insider generates the following expected profit: ${ }^{9} \Pi_{t}=-\varepsilon_{t}+\sum_{t=0}^{\infty} \delta^{t}(1-\phi)^{t}(a-w)-$ $\delta \phi f \sum_{t=0}^{\infty} \delta^{t}(1-\phi)^{t}$.

The insider is fired when $\Pi_{t}<-f$, so that $\varepsilon_{t}>(a-w+(1-\delta) f) /(1-\delta(1-\phi))$. Thus the firing rate is given by the following implicit function: ${ }^{10}$

\footnotetext{
${ }^{7}$ The capital stock is not modeled endogenously. Changes in wages have a substitution and scale effect. The overall outcome depends on their relative magnitude.

${ }^{8}$ For a detailed description of the sequencing see Appendix.

${ }^{9}$ In what follows, only those variables have time subscripts that, for given parameter values, actually vary through time in our model.

${ }^{10}$ We assume that $(\partial \Gamma / \partial \phi)>-1$, so that a rise in $(a-w)$ or $f$ both reduce the firing rate.
} 


$$
\phi=1-\Gamma\left(\frac{a-w+(1-\delta) f}{1-\delta(1-\phi)}\right)
$$

Given a hiring cost $h$ per worker (a constant), an entrant is hired when $\Pi>h$, so that the hiring rate is

$$
\eta=\Gamma\left(\frac{a-w-\delta \phi f}{1-\delta(1-\phi)}-h\right)
$$

The change in employment $\left(\Delta N_{t}\right)$ is the difference between the hiring from the unemployment pool $\left(\eta U_{t-1}\right)$ and the firing from the employment pool $\left(\phi N_{t-1}\right)$, where $U_{t-1}$ and $N_{t-1}$ are the aggregate unemployment and employment levels: $\Delta N_{t}=$ $\eta U_{t-1}-\phi N_{t-1}$. Letting $\left(n_{t}=N_{t} / L_{t}\right)$ be the employment rate and $g_{t}$ be the labor force growth factor $\left(g_{t}=L_{t} / L_{t-1}\right)$, this implies the following employment dynamics equation:

$$
n_{t}=\frac{1}{g_{t}}\left(\eta+(1-\eta-\phi) n_{t-1}\right)
$$

and similarly for West Germany.

In this context, the massive East German wage hike after reunification reduced the hiring rate $\eta$ and thereby led to a sharply lower employment rate $n_{t}$ (due to a downward shift of curve (3)). Furthermore, this East German employment collapse became long-lived since reunification raised the degree of employment persistence. Specifically, the reunification-induced increase in job security (raising firing costs) and labor market regulations (raising hiring costs), reduced the hiring and firing rates $(\eta$ and $\phi)$ and thereby raised the employment persistence parameter $(1-\eta-\phi) / g_{t}$, ceteris paribus.

\subsection{Migration}

\subsubsection{Theoretical Framework}

Labor force growth in our model depends only on migration. Assuming for simplicity that household per-period utility is equal to consumption (no disutility of work), migration depends on the difference between the expected present values of income to be earned in East and West.

In equilibrium, an insider's present value in the East is $V_{i}=w+\delta\left((1-\phi) V_{i}+\phi V_{o}\right)$, and for an entrant it is $V_{o}=b+\delta\left(\eta V_{i}+(1-\eta) V_{o}\right)$, which can be solved for $V_{i}$ and $V_{o}$. Assume that East German insiders and outsiders become outsiders in West Germany. Let $\widehat{V}_{i}, \widehat{V}_{o}>V_{o}$, implying migration from East to West.

Workers are heterogeneous in terms of their mobility costs, which are iid across workers and through time. For simplicity, we view the migration cost solely as a congestion-type cost, letting the cost of the marginal migrant be $\kappa\left(m_{j t}\right), j=i, o ; \kappa^{\prime}$, 
$\kappa ">0$; where $m_{j, t}=M_{j, t} / L_{t}, M_{j, t}$ is the number of migrants $j$, and $M_{i, t}+M_{o, t}=$ $\Delta L_{t}$. Setting this cost equal to the gain from migration for the marginal insider and outsider, we obtain the aggregate migration rate: ${ }^{11}$

$$
m=g-1=\kappa^{-1}\left(\widehat{V}_{o}-V_{i}\right)+\kappa^{-1}\left(\widehat{V}_{o}-V_{o}\right) .
$$

A rise in the East German wage $w$ (ceteris paribus) has countervailing effects: it raises the attractiveness of East German jobs, thereby reducing migration from East Germany; it also reduces the hiring rate and raises the firing rate in East Germany, thereby increasing migration. In the calibrated model below, the former effect dominates, so that an East German wage increase reduces migration. A fall in migration, in turn, reduces the growth rate of the West German labor force and thereby increases the West German employment rate (by the West German counterpart of eq. (3)). In short, a rise in the East German wage leads to a rise in the West German employment rate.

\subsubsection{Empirical Evidence}

The empirical literature provides evidence in favor of the hypothesis that higher wages have reduced the migration flows from East to West. The wage differential for migrants shows a positive impact on the propensity to migrate (Herbert Brücker and Parvati Trübswetter, 2004). Michael Burda and Jennifer Hunt (2001) analyze the effects of the wage level in source and destination states on the actual propensity to migrate. For the beginning of the nineties they conclude that "on balance, high wages in the East reduced emigration" (p. 62), whereas they have difficulties in explaining the rise of the East-West migration in 1998 by the actual wage and unemployment levels. They attribute it to a change of expectations, specifically, the anticipation among East Germans that there will be no complete wage adjustment in the near future. ${ }^{12}$

It is worth noting that the empirical literature does not find a clear-cut relationship between income and migration. For example, Michael Burda (1993), and Michael Burda et al. (1998) present a U- or S-shaped form, which they attribute to the option value of waiting. Observe, however, that this stream of the literature analyzes the effect of household income on migration, and thus does not adopt our approach of focusing on differentials in the expected present value of future income streams. We are not aware of any empirical study that analyzes the effect of present value differentials on the propensity to migrate.

\footnotetext{
${ }^{11}$ In the long run, we expect some mechanism to come into operation, so that net migration comes to an end (e.g. equalization of East-West income differentials). Since this tendency has been minor since reunification, we leave it out of our current analysis.

${ }^{12}$ In our calibration model below, we assume perfect foresight over the sample period, and thus expectational swings are captured only insofar as they turn out to be realistic.
} 
An indirect way of assessing the consequences of high wages is to examine how East German wage increases affect the overall East German wage bill. For this purpose, it is necessary to estimate the elasticity of labor demand (under the assumption that, in the presence of substantial East German unemployment, employment decisions are determined by the labor demand). A short-run labor demand elasticity greater than minus one of course implies that the overall wage bill rises in the short run when wages increase. Regina Riphan et al. (1999, p. 27), surveying the empirical literature for Germany as a whole on this issue, find that almost all the estimated labor demand elasticities lie well beneath 1 in absolute terms. ${ }^{13}$

Bernhard Heitger (2001) or Felix FitzRoy and Michael Funke (1998) estimate effects of wages on employment for East Germany that are usually either greater than -1 or not significantly different from zero, which is consonant with our assumption that an East German wage hike raises East German income. ${ }^{14}$

\subsection{Wage Determination}

\subsubsection{Theoretical Framework}

We consider two types of wage negotiations: (i) "self-sufficient bargaining", in which the bargaining parties determine their own wages (the standard wage bargaining framework) and (ii) "bargaining by proxy". We represent West German wage bargaining as self-sufficient. We view East German wages after unification as reflecting both types of wage negotiations, with bargaining by proxy gradually giving way to self-sufficient bargaining with the passage of time.

Under self-sufficient bargaining, let the wage be the outcome of a bargain between each insider and his firm. The wage is renegotiated in each period. Under bargaining agreement, the insider receives the wage $w$, and the firm receives the expected profit $(a-w)$ in each period. Under disagreement, the insider's fallback income is $b$, assumed equal to the unemployment benefit, and the firm's fallback profit is $-f$, i.e. during disagreement the insider imposes the maximal cost on the firm (e.g. through strike, work-to-rule, sabotage) short of inducing dismissal. Assuming that disagreement in the current period does not affect future returns, the insider's surplus is $w-b$ and the firm's surplus is $a-w+f .{ }^{15}$ The negotiated wage maximizes the Nash

\footnotetext{
${ }^{13}$ Wolfgang Franz and Heinz König (1986), Ernst Stark and Günter Jänsch (1988), Gebhard Flaig and Viktor Steiner (1989), Kornelius Kraft (1991), Klaus Zimmermann and Thomas Bauer (1997), Hermann Buslei and Viktor Steiner (1999), and Martin Falk and Betrand Köbel (2001) all estimate labor demand elasticities that are consonant with our theory. The only outlier is Lioba Trabert et al. (1998).

${ }^{14}$ One exception in Fitzroy and Funke's (1998) paper is the estimated short-run elasticity for low-skilled in East German manufacturing, which is smaller than -1 (-1.26), but statistically not different thereof at a $95 \%$ confidence level.

${ }^{15}$ Specifically, the expected present value of returns under agreement are $V_{i, t}=w_{t}+$ $\delta\left(\left(1-\phi_{t+1}\right) V_{i, t+1}+\phi_{t+1} V_{o, t+1}\right)$ and $\widetilde{\Pi}_{t}=\left(a_{t}-w_{t}\right)+\delta\left(\left(1-\phi_{t+1}\right) \widetilde{\Pi}_{t+1}-\phi_{t+1} f_{t+1}\right)$, for the in-
} 
product $(w-b)^{\mu}(a-w+f)^{1-\mu}$, where $\mu$ represents the bargaining strength of the insider relative to the firm (assumed equal in East Germany and West Germany). Similarly for the West German wage. Thus the negotiated wages are

$$
w=(1-\mu) b+\mu(a+f), \quad \hat{w}=(1-\mu) \hat{b}+\mu(\hat{a}+\hat{f})
$$

We conceive of bargaining by proxy as a broad-based process, supported by public institutions, involving all West German firms and workers (not just the insiders). The bargaining parties are concerned with the East German wage because, as noted, it positively affects the West German employment rate.

A rise in the West German employment rate, in turn, raises the West German workers' payoff and reduces the West German firms' payoff, along the following lines. Let the average incomes of West German outsiders and insiders (per period) be $\hat{y}_{o}=$ $\hat{\eta} \hat{w}+(1-\hat{\eta}) \hat{b}$ and $\hat{y}_{i}=(1-\hat{\phi}) \hat{w}+\hat{\phi} \hat{b}$, respectively. Then the average West German worker's bargaining surplus per period $t+j$ is $\hat{y}_{o}\left(1-\hat{n}_{t+j}\right)+\hat{y}_{i} \hat{n}_{t+j}-\widetilde{y}$, where $\widetilde{y}$ is the fallback income under bargaining disagreement (exogenously given). This surplus rises with the employment rate. For simplicity, let $\hat{y}_{o}=\widetilde{y}$, so that the West German worker's per-period surplus reduces to $\left(\hat{y}_{i}-\hat{y}_{o}\right) \hat{n}_{t+j}$. Thus the present value of the worker's surplus is

$$
\Lambda_{w}=\left(\left(\hat{y}_{i}-\hat{y}_{o}\right) \sum_{j=0}^{\infty} \delta^{j} \hat{n}_{t+j}\right) .
$$

Under bargaining agreement, the average firm receives $\widehat{a}-\widehat{w}-\widehat{f} \widehat{\phi} \widehat{n}-\widehat{h} \widehat{\eta}(1-\widehat{n})$ per period; under disagreement, it receives $-f$. Thus its surplus per period is $\widehat{\sigma}_{a}-\widehat{\sigma}_{n} \hat{n}_{t}$, where $\widehat{\sigma}_{a}=\widehat{a}-\widehat{w}-\widehat{h} \widehat{\eta}+\widehat{f}$ (autonomous surplus) and $\widehat{\sigma}_{n}=\widehat{f} \widehat{\phi}-\widehat{h} \widehat{\eta}$ (induced surplus). We assume that $\widehat{\sigma}_{n}>0$, so that, plausibly, the firm's surplus falls with the employment rate. ${ }^{16}$ The present value of the firm's surplus is

$$
\Lambda_{f}=\sum_{j=0}^{\infty} \delta^{t}\left(\widehat{\sigma}_{a}-\widehat{\sigma}_{n} \hat{n}_{t+j}\right) .
$$

Thus bargaining by proxy can be expressed in terms of a bargain over the West German employment rate $\hat{n}_{t}$. The Nash product is $\left(\Lambda_{w}\right)^{\mu}\left(\Lambda_{f}\right)^{1-\mu}$, to be maximized

sider and the firm, respectively. (Since the wage is renegotiated in each period, the present value in period $t$ is independent of the present value in period $t+1$.) Since disagreement in the current period does not affect future returns, the present value of returns under disagreement are $V_{i, t}^{\prime}=b_{t}+\delta\left(\left(1-\phi_{t+1}\right) V_{i, t+1}+\phi_{t+1} V_{o, t+1}\right)$ and $\widetilde{\Pi}_{t}^{\prime}=-f_{t}+\delta\left(\left(1-\phi_{t+1}\right) \widetilde{\Pi}_{t+1}-\phi_{t+1} f_{t+1}\right)$, for the insider and the firm, respectively. Thus the insider's surplus is $V_{i, t}-V_{i, t}^{\prime}=w_{t}-b_{t}=w-b$ and the firm's surplus is $\widetilde{\Pi}_{t}-\widetilde{\Pi}_{t}^{\prime}=a_{t}-w_{t}+f_{t}=a-w+f$.

${ }^{16}$ In practice, there are of course many other reasons why the firms' surplus falls as the employment rate rises, e.g. firms' costs of searching for workers rise, and firms' fall-back positions deteriorate (since insiders are likely to be more aggressive during bargaining disagreement). 
with respect to $\hat{n}_{t}$. Since the present values $\Lambda_{w}$ and $\Lambda_{f}$ are time-invariant, the bargaining solution is time-invariant as well: $\hat{n}_{t}=\hat{n}$. Solving the Nash bargaining problem, we obtain the following target West German employment rate:

$$
\widehat{n}=\mu \frac{\widehat{\sigma}_{a}}{\widehat{\sigma}_{n}}
$$

The West German bargainers achieve this target employment rate by setting the East German wage $w$.

The greater the workers' bargaining strength $\mu$, the greater is the West German target employment rate and the higher the East German wage will be set. The lower the migration costs $\kappa$, the higher will be the East German wage corresponding to a given West German target employment rate. In this way, our model shows why the East German labor market suffered on account of purported "advantages" of the East Germans - the ability to migrate to the wealthy West and increased bargaining strength bestowed by their Western counterparts.

\subsubsection{Empirical Evidence}

There is a large body of evidence, largely anecdotal, documenting the dominant role of West Germans in East Germany's wage bargaining. For example, Wolfgang Schröder (2000, p. 9 f.) examines the role of Germany's largest industrial union IG Metall ${ }^{17}$ and its counterpart employers' association: "Im Gewerkschaftsbereich bestand für einige Monate eine sichtlich belastende Konkurrenzsituation zwischen der bundesdeutschen IG Metall und der IG Metall/DDR. Mit der Ankündigung der Währungsunion und der Präferenz für das Beitrittsmodell ging die Federführung auf die westdeutsche Seite über. Für Arbeitgeberverbände und IG Metall ergaben sich daraus unterschiedliche organisationspolitische Strategien. Auf Arbeitgeberseite wurden zwar die ostdeutschen Funktionäre formal bestätigt; real wurde jedoch für einen nicht weiter definierten Zeitraum ein paternalistisches Lehrer-Schüler-Verhältnis installiert, mit dem die faktische tarifpolitische Entscheidungskompetenz bei den westdeutschen Verbänden lag. Während die ostdeutschen Arbeitgeberverbände integriert wurden, musste sich die IG Metall/DDR auflösen. Deren Führungselite wurde durch eine westdeutsche Funktionärsschicht ersetzt, die den Aufbau nach westdeutschen Vorgaben und Erfahrungen gestalten sollte." (authors' translation: "In the union sector there was costly competition between the West German metal working union, IG Metall, and its counterpart from East Germany for a couple of months. With the announcement of the monetary union and the preference for accession, the decision-making was handed over to the West German side. This gave rise to different organizational strategies for employers' associations and the union IG Metall. On the employers' side the East German officials were in fact confirmed officially. But in reality there was a paternalistic teacher-pupil relationship for an indefinite time period, which gave

\footnotetext{
${ }^{17}$ Responsible for the metal-working industry.
} 
the de facto decision making power to the West German associations. While East German employers' associations became integrated into the negotiation process, the East German metal working union had to disband. Its leadership elite was replaced by a West German shift of officials, which were to pursue East German reconstruction according to West German guidelines.") This view is e.g. confirmed by Fitzroy and Funke (1996, p. 460): "Initial collective bargaining was conducted between west German unions (in the absence of legitimate union representatives in East Germany) and managers of the existing large state-owned enterprises. As is well-known, a succession of wage increases to the western level was agreed in the initial round of negotiation." The influence of the unions on East German wage negotiations was widespread. For instance, Michael Burda and Michael Funke (1993, p. 541) write that the "unions were recognized by eastern German employers as the de facto negotiating partner in collective bargaining and were thereby able to conclude wage agreements in almost every industrial sector and many of the service branches. The adoption of west German labor laws by the GDR [German Democratic Republic], including those governing severance, made this organizational campaign easier." We take these and many other observations as evidence in favor of our "bargaining by proxy" hypothesis.

Furthermore, our analysis suggests East German wage negotiations are emancipating themselves from West German influence. This is of course a gradual process. Supporting evidence is that the membership rate of East German unions halved from 1992 to 2002, while the reduction in West Germany during the same time period was more modest.

\begin{tabular}{||l||l||l||}
\hline \hline Union Members / Employed & East Germany & West Germany \\
\hline \hline Year 1992 & $39.7 \%$ & $28.7 \%$ \\
\hline \hline Year 1996 & $26.7 \%$ & $26.6 \%$ \\
\hline \hline Year 2002 & $20.4 \%$ & $23.8 \%$ \\
\hline \hline
\end{tabular}

Table 1: Union Membership, Source: Claus Schnabel (2005, p. 8).

Moreover, in 2000, three quarters ${ }^{18}$ of East German companies were not tied to a collective bargaining agreement (see e.g. Susanne Kohaut and Claus Schnabel, 2001), whereas this number was as low as $25 \%$ in 1993.

There were many signs of resistance to West German influence on East German wage bargaining. For example, in 1993 the employer's association in the metal working industry dropped a collective bargaining agreement that would have claimed wage increases of 26\% (see Georg Czada, 1998). In 2003 Germans witnessed an important symbolical event which signal how far the emancipation from the West had progressed. The powerful trade union IG Metall tried to introduce the 35-hour week in East Germany, which would have pushed regular working time down to the same level as in West Germany. To achieve enough manpower for the strike, the trade union IG Metall had to bring supporters from West Germany to the East, and these supports

\footnotetext{
${ }^{18}$ The rate was about $50 \%$ for West Germany.
} 


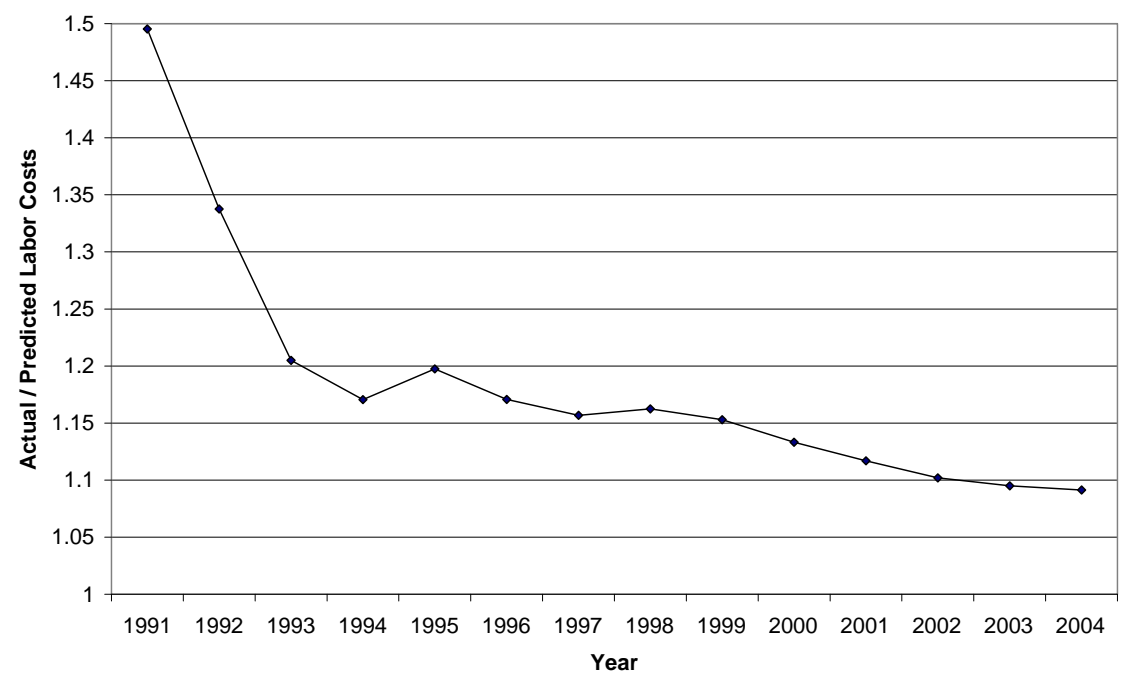

Figure 1: Actual labor costs divided by the predicted labor costs under self-sufficient bargaining.

attempted to prevent East German workers from entering their firms. In the end, the resistance of the East German work force and employers to this "helping hand" became overwhelming and the 35-hour week was not implemented in the East.

East German labor cost data is also suggestive. In Figure $(1)^{19}$, we compare actual East German labor costs to the values predicted by our self-sufficient bargaining model (for details of the calculation see Section 4 and Appendix). Note that the relative difference between the actual and predicted numbers has fallen steadily. We would interpret a ratio of 1 as East Germans bargaining for their wages entirely selfsufficiently. Our model suggests that West Germans still have a hand in the East German bargaining process, although the influence has gone down significantly.

\subsection{The East German Labor Market Equilibrium}

\subsubsection{Theoretical Framework}

The East German labor market equilibria are pictured in Fig. 1. The initial employment dynamics line $E_{0} E_{0}^{\prime}$ (corresponding to eq. (3), with its long-run equilibrium point $A$ ) is hypothetical: it illustrates East German employment in the absence of the "caring hand". Line $E_{1} E_{1}^{\prime}$ depicts employment in the immediate aftermath of reunification, reflecting the influence of high wages due to bargaining by proxy and increased employment persistence $\left(E_{1} E_{1}^{\prime}\right.$ is steeper than $\left.E_{0} E_{0}^{\prime}\right)$. The employment

\footnotetext{
${ }^{19}$ Numbers for the five new "Länder", excluding Berlin. Source: Statistische Ämter des Bundes und der Länder (2005), own calculations.
} 




Figure 2: East German Employment

persistence implies that the wage hike dampens employment gradually (e.g. the movement from point $A$ to $B$ ). This is consonant with the fall of the East German employment rate in the first part of the 1990s. Finally, $E_{2} E_{2}^{\prime}$ describes employment once East Germans will gain direct control over their wages, so that East German wages fall somewhat relative to productivity. $E_{2} E_{2}^{\prime}$ lies well beneath $E_{0} E_{0}^{\prime}$ on account of generous unemployment benefits and firing costs, keeping wages high. Thus the employment rate rises somewhat, but then remains at a high level (at point $\mathrm{C}$ ).

\subsubsection{Empirical Evidence}

East Germany inherited the West German job security legislation with the social and monetary union in 1990. The empirical literature shows that the German (or continental European) labor markets show greater persistence than their Anglo-Saxon counterparts (see e.g. Christoph Schmidt, 1999). Fitzroy and Funke (1996) find a higher persistence for the labor demand for skilled and medium skilled labor in East Germany than in West Germany, whereas the opposite is the case for low-skilled labor (0.77 (0.34) for skilled workers in East Germany (West Germany), 0.73 (0.37) for semi-skilled and 0.48 (0.68) for low skilled).

\section{Traps}

\subsection{Theory}

While the model helps explain why the East German employment rate fell gradually in the aftermath of unification, it does not shed light on East Germany's stagnating 
employment rates. For this purpose, we consider the following labor market "traps":

The low-skill trap: Due to generous unemployment benefits, associated welfare entitlements, and job security provisions, wages relative to productivity remained particularly high for East German unskilled workers, who thus became especially unemployment-prone. Without jobs, they could not get on-the-job training and become integrated in the workforce, thus falling into a low-skill unemployment trap.

The ageing trap: Since the younger workers have a longer time horizon over which they earn wage income, to be set against the fixed cost of migrating, the younger East Germans have had a greater incentive to migrate to the West, where expected income is higher. This incentive was reinforced by the post-unification wage hike: since the elasticity of labor demand is smaller in the short run than in the long run, the wage hike raised wage income more in the short run, i.e. the time span relevant to older workers. Insofar as older workers are less flexible and versatile than their younger counterparts, this may lead to less flexible and versatile capital accumulation. Thereby the East became susceptible to an "ageing trap" in which old skills and old capital dampened labor productivity and thus labor demand.

The labor-saving trap: Due to the post-unification wage hike and investment subsidies, it became profitable for firms to invest in labor-saving physical capital. Once this capital was in place, it was of course more difficult to find jobs for East Germany's unemployed. Investment in labor-saving capital raised incentives for workers to acquire the associated "labor-saving labor" skills. The resulting equilibrium, "labor-saving capital-skills trap," economizes on labor, despite high unemployment.

The "wrong" capital-skills trap: The vast investment subsidies in East Germany generated capital that propped up uncompetitive enterprises and was designed to prevent layoffs in declining industries. Firms had relatively little incentive to avoid underutilization of such capital. This phenomenon provides an explanation for the puzzling phenomenon that labor productivity is generally lower in the East than West, even though capital intensity is comparable or higher. We hypothesize that the "wrong capital" is complementary with "wrong skills", which also tend to be underutilized. The resulting trap helps keep East Germans unemployment-prone and dependent on hand-outs from the West.

The nontradable trap: The massive subsidies from West Germany triggered a rapid rise of product demand in East Germany. Thus the prices of nontradables rose, while tradable prices remained perforce unchanged (while "imports" of tradables from West to East rose). This, combined with wage compression between East and West (due to bargaining by proxy, uniformly generous unemployment benefits and job security provisions), caused real producer wages to rise much faster in the tradable than the nontradable sector. The resulting reallocation of labor towards the nontradable sector led to higher unemployment in the transition. Some of this unemployment persisted since retraining takes time and many unemployed workers remained jobless due to generous unemployment benefits, lack of on-the-job training, and retraining costs. 


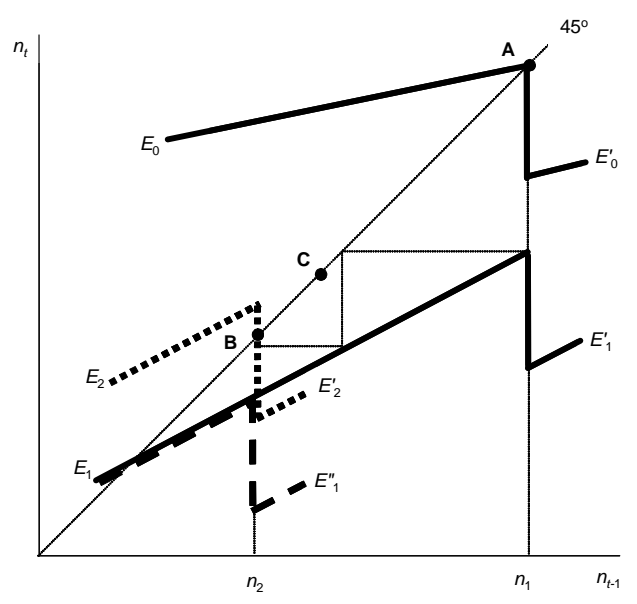

Figure 3: Traps: A Simple Depiction

To begin with, we consider a particularly simple way of incorporating them in our previous analysis. Divide the labor market into an "employment creating" sector $(E C)$ and an "employment destroying" sector $(E D)$. In the "low-skill trap," skilled labor (with a relatively high employment rate) is in $E C$, whereas low-skilled or unemployed labor is in $E D$. In the "ageing trap," $E C$ employs young labor and flexible capital (with expanding labor demand) and $E D$ employs old labor and traditional capital (with stagnant labor demand). In the "labor-saving trap," $E C$ uses laborusing skills whereas ED uses labor-saving skills. In the "wrong capital-skills trap," $E C$ employs competitive capital and skills, whereas in $E D$ they are defensive.

We now amend the model above by supposing that $E C$-workers have higher productivity than $E D$-workers, but that workers' wages are compressed due to unemployment benefits, firing costs, etc. Then $E C$-workers are more profitable and thus have higher hiring rates and lower firing rates than $E D$-workers $\left(\eta_{E C}>\eta_{E D}, \phi_{E C}<\phi_{E D}\right)$. Suppose that firms give preference to $E C$-workers, employing $E D$-workers only once $E C$-workers are not available. Then the employment dynamics curve has a kink at the initial equilibrium point $A$, as illustrated by the curve $E_{0} E_{0}^{\prime}$ in Fig. $2 .^{20}$

In this context, the post-unification wage hike shifts the kinked curve downward from $E_{0} E_{0}^{\prime}$ to $E_{1} E_{1}^{\prime}$ in the figure. Thus employment falls from $n_{1}$ to $n_{2}$ (over two periods in the figure). Then the newly unemployed workers $n_{2}-n_{1}$ lose their $E C$ skills. So the number of $E C$-workers shrinks and the kink moves leftward to $n_{2}$, so that the employment dynamics curve becomes $E_{1} E_{1}^{\prime \prime}$.

Finally, suppose that after two periods, the wage falls back partially, as East Germany gains control over its wage bargaining, so that the employment dynamics

\footnotetext{
${ }^{20}$ The figure assumes, for simplicity, that $\Gamma^{\prime \prime}=0$, so that $\partial \eta / \partial a=-\partial \phi / \partial a$, and thus the employment persistence parameter is the same for $E D$ - and $E C$-workers.
} 
curve shifts to $E_{2} E_{2}^{\prime}$. Provided that this upward shift is smaller than the size of the kink, then the equilibrium employment rate remains at point $B$ (rather than point $C$, the final equilibrium in Fig. 1): the labor market is in a "trap."

\subsection{Skills and Vacancies}

We now elaborate our trap theory by taking account of the interaction between workers' skills acquisition decisions and firms' vacancy decisions. Suppose that the two sectors require sector-specific skills. Workers decide what skills to acquire, taking account of what types of jobs are available; and firms offer jobs, taking account of what skills are available.

The intuition underlying our "traps" is simple. The rise in Eastern wages after reunification gave firms an incentive to offer more jobs in $E D$ and less in $E C$. Thereby Eastern workers gained an incentive to invest in $E D$ skills (or not to invest in skills at all, as in the low-skill trap). This interaction between workers' skill decisions and firms' vacancy decisions amplify the initial effect of the Eastern wage hike. The resulting preponderance of $E D$ skills become "sticky" due to the fixed costs of skill acquisition (e.g. vocational and further education). Since such human capital investment is typically costly and lengthy, the resulting skills decisions can be undone only by a employment-creating shock (e.g. a fall in wages) that is sufficiently large to exceed the fixed costs of skill acquisition. We argue, however, that such a large shock did not occur due to the social and institutional union, which bolstered firing costs, unemployment benefits and other welfare entitlements and thereby maintained firms' incentives to economize on labor and reduced workers' incentives to seek jobs. Thus the East German labor market is in a trap, where the nature of skills and vacancies perpetuate a low-employment equilibrium.

While it is straightforward to extend our model to cover skill acquisition, for brevity we simplify the analysis to focus solely on the interaction between skills and vacancies.

\subsubsection{The Skill Acquisition Decision}

Let the worker's gain from acquiring skills be $\rho_{i} w_{i}-\left(1-\rho_{i}\right) b_{i}$ where $\rho_{i}$ is the probability of finding a job in sector $i=E C, E D{ }^{21}$ The number of matches in each market depends on the number of searchers $\left(M_{i}\right)$ and the number of vacancies $\left(V_{i}\right)$ : $X_{i}=A_{i} M_{i}^{\alpha} V_{i}^{1-\alpha}$.

The searchers $M_{i}$ for jobs in sector $i$ are the unemployed workers with the skills relevant for that sector. This group is composed of those who were previously employed in this sector and lost their jobs $\left(M_{i}^{o}\right)$ and those who have not been employed

\footnotetext{
${ }^{21}$ For simplicity, but without affecting our qualitative conclusions, we assume that workers and firms have a one-period time horizon.
} 
in this sector but who have acquired the necessary skills previously. The worker's probability of finding a job is $\rho_{i}=\frac{X_{i}}{M_{i}}=A_{i}\left(\frac{V_{i}}{M_{i}}\right)^{1-\alpha}$.

Let the marginal cost of training for a worker without previous training in sector $i$ be $\tau_{i}$ (a positive constant) and and let the corresponding cost for a worker who has previously been employed in the relevant sector be $\tau_{i}^{o}$ (another positive constant), where $\tau_{i}>\tau_{i}^{o}$.

Since the traps are concerned with misallocations of labor between sectors, we focus on movements of labor from $E C$ to $E D$ or in the opposite direction. In equilibrium, the marginal benefits from skill acquisition is equal to the associated marginal cost. Thus we obtain the following skills function, where the relative benefits of acquiring skills are equal to the relative costs across sectors:

$$
\begin{aligned}
& \frac{V_{E D}}{V_{E C}}=\left(\frac{c_{E D}}{c_{E C}^{o}}\right)^{\frac{1}{1-\alpha}} \frac{M_{E D}}{M_{E C}}, \text { for } M_{E D}>M_{E D}^{o} \text { and } M_{E C} \leq M_{E C}^{o} \\
& \frac{V_{E D}}{V_{E C}}=\left(\frac{c_{E D}^{o}}{c_{E C}}\right)^{\frac{1}{1-\alpha}} \frac{M_{E D}}{M_{E C}}, \text { for } M_{E D} \leq M_{E D}^{o} \text { and } M_{E C}>M_{E C}^{o}
\end{aligned}
$$

where $c_{i}=\frac{\tau_{i}+\beta w_{i}}{w_{i}(1-\beta) A_{i}}, \quad c_{i}^{o}=\frac{\tau_{i}^{o}+\beta w_{i}}{w_{i}(1-\beta) A_{i}}$.

\subsubsection{The Vacancy Decision}

The firm's physical capital decision is modeled simply in terms of supplying vacancies in each sector. The expected gross profit per employee (excluding vacancy costs) is $\theta_{i}\left(a_{i}-w_{i}\right)$, where $\theta_{i}$ is the firm's probability of finding a worker with the relevant skills. Firms are heterogeneous in terms of their costs of supplying vacancies, so that their marginal firm's cost of supplying vacancies rises with the aggregate number of vacancies supplied: $\kappa_{i} V_{i}^{\delta}$, where $\delta>1$ is a constant. Firms enter each sector until the marginal gross profit is equal to the marginal cost of supplying vacancies: $\theta_{i}\left(a_{i}-w_{i}\right)=\kappa_{i} V_{i}^{\delta}$. The probability of finding a worker with the relevant skills is $\theta_{i}=\frac{X_{i}}{V_{i}}=A_{i}\left(\frac{M_{i}}{V_{i}}\right)^{\alpha}$.

Thus we obtain the following vacancy function, where the relative benefits of supplying vacancies are equal to the relative costs across sectors:

$$
\frac{V_{E D}}{V_{E C}}=\left(\frac{d_{E C}}{d_{E D}}\right)^{\frac{1}{\alpha+\delta}}\left(\frac{M_{E D}}{M_{E C}}\right)^{\frac{\alpha}{\alpha+\delta}}
$$

where $d_{i}=\frac{\kappa_{i}}{A_{i}\left(a_{i}-w_{i}\right)}$.

\subsubsection{The Labor Market Equilibrium}

The skills function is depicted by $S F$ in Fig. 3. Since $\tau_{i}>\tau_{i}^{o}$, the lower branch of this function is flatter than the upper branch and there is a kink between the two 


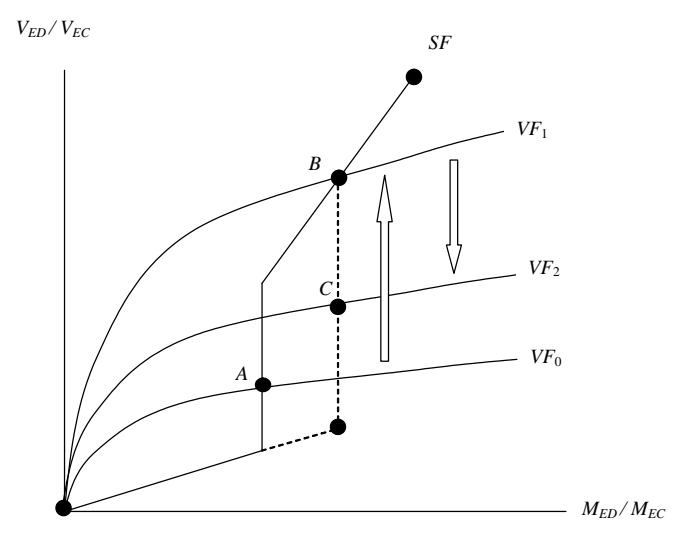

Figure 4: Traps: Skills and Vacancies

branches. The vacancy function is $V F$. The labor market equilibrium lies at the intersection of $S F$ and $V F$.

Starting from a hypothetical initial equilibrium point $A$, wages rise due to bargaining by proxy. ${ }^{22}$ Thus the relative profitability of the $E D$ sector rises, so that the vacancy supply function shifts upwards from $V F_{0}$ to $V F_{1}$. The new equilibrium is at point $\mathrm{B}$ and the corresponding skills function has a kink that passes through point C.

Finally, wages fall back partially (as Easterners gain control over their wages) and the vacancy function down from $V F_{1}$ to $V F_{2}$. Provided that this shift is smaller than the size of the kink in the skills function, then the relative skill endowment $M_{s} / M_{u}$ remains unchanged and the economy remains trapped with the relatively large share of workers with $E D$ skills.

\subsection{Empirical Evidence}

Figure (5) shows that the number of employees in East Germany ${ }^{23}$ has fallen enormously since 1990. The tendency is even more pronounced for the industry or the tradable sector in general.

The East German competitive position has been affected dramatically by the 1:1 exchange rate adoption and bargaining by proxy. Sinn (2002, p. 118) writes

\footnotetext{
${ }^{22}$ The figure assumes for simplicity that this wage hike hits both sectors proportionately, so that relative wages between the two sectors remain unchanged and $S F$ is unchanged as well.

${ }^{23}$ Excluding Berlin. For the development we use the numbers from Statistische Ämter des Bundes und der Länder (2005) from 1991 to 2004. The percentage change from 1990 to 1991 is calculated by using the number of dependent employed people from DIW (1993, p. 256) and DIW (1994, p. $731)$.
} 


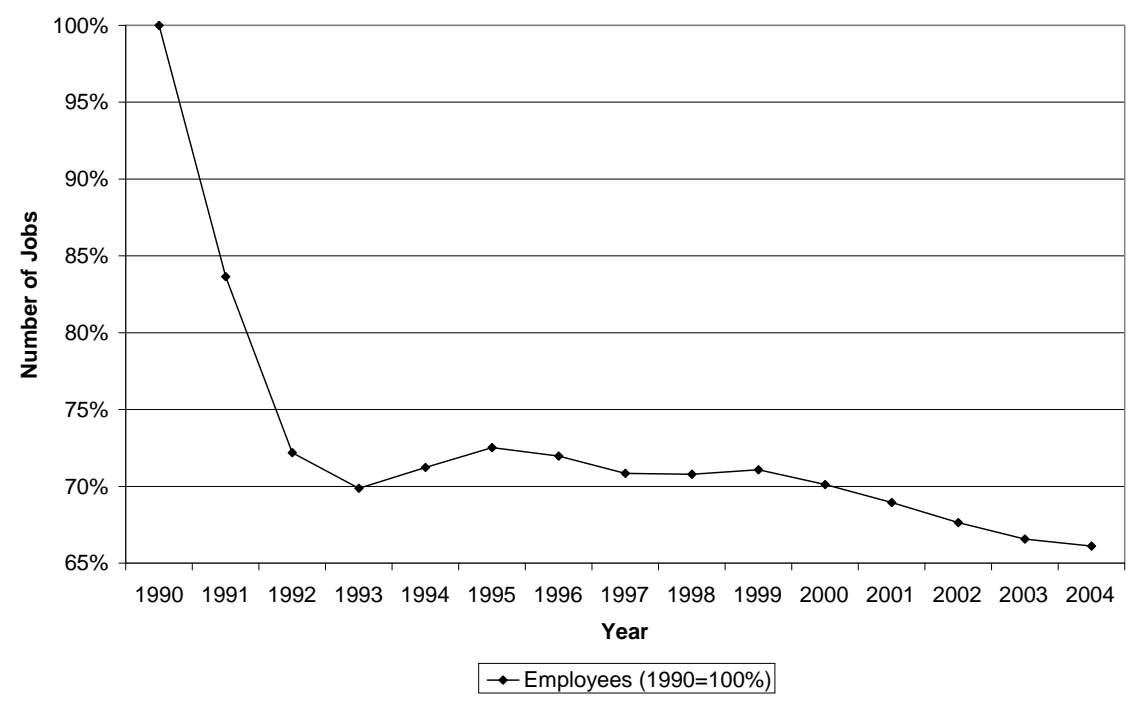

Figure 5: Trapped!

that labor costs were only $7 \%$ of the West German level before unification. The ratio has reached about $50 \%$ in $1991 .{ }^{24}$ Bargaining by proxy has strengthened this development. Werner Smolny (2003) shows that nominal labor costs where increasing by about a quarter from 1990 to 1991, while the labor productivity was falling slightly.

Figure $(6)^{25}$ illustrates an important puzzle: although the labor cost normalized by productivity have almost steadily fallen since 1991, the East German employment rate has shown no substantial sign of improvement since 1992. The initial labor cost shock had extremely long after-effects, which cannot be entirely explained by labor market persistence. This provides support for the existence of labor market traps.

We provide empirical evidence for consequences of the different traps, explained in the theoretical section:

The low-skill trap: The unemployment rate among people without qualification in East Germany jumped from around 30\% in 1991 to more than a half at the end of the nineties (DIW Berlin et al., 2002, p. 342).

The ageing trap: The empirical literature provides support that young people have a higher propensity to migrate (see e.g. Burda, 1993, Burda et al., 1998, Felix Büchel and Johannes Schwarze, 1994, Brücker and Trübswetter, 2004). Burda and Hunt (2001) and Jennifer Hunt (2000) write that movers are on average eleven to

\footnotetext{
${ }^{24}$ Own calculations. We divided the labor cost per employee in East Germany by the number in West Germany (excluding Berlin entirely). Source: Statistische Ämter des Bundes und der Länder (2005).

${ }^{25}$ All numbers for East Germany without Berlin. The employment rate is defined as (1-official unemployment rate), excluding self-employed. Source: Statistische Ämter des Bundes und der Länder (2005) and Bundesagentur für Arbeit (2006).
} 


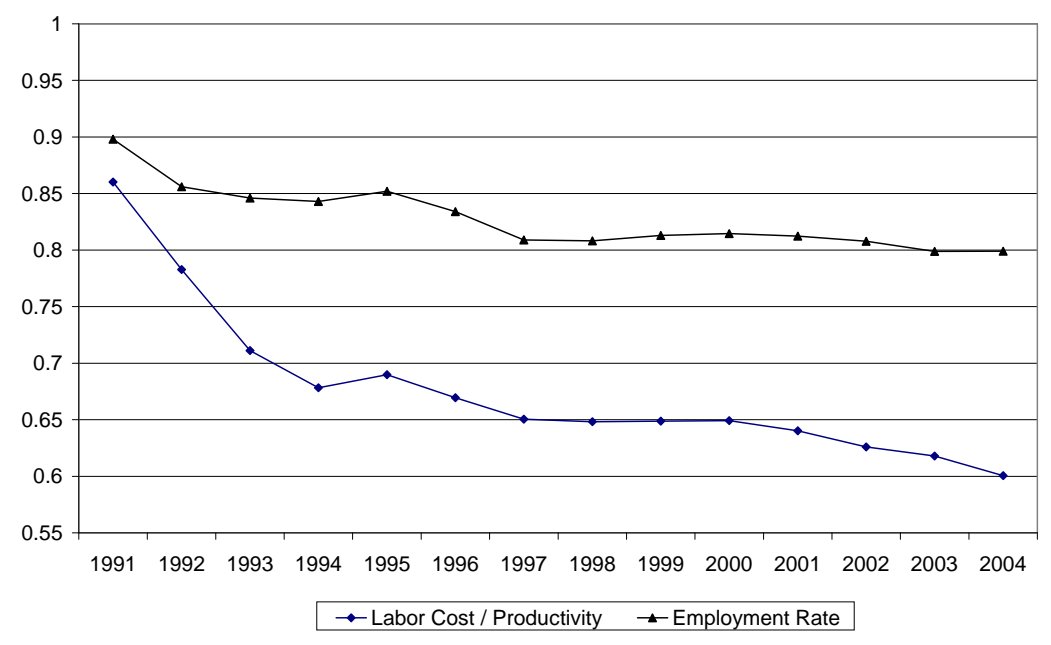

Figure 6: East German labor cost normalized by productivity and the employment rate.

fifteen years younger than stayers.

Further evidence is provided by the Institut für Arbeitsmarkt- und Berufsforschung (2005), which predicts that the potential labor force ${ }^{26}$ in East Germany will fall from 10 million today to about 4.5 million people in 2050, whereas the drop in West Germany will be more moderate (from 40 to 30 million people). ${ }^{27}$

The labor-saving trap: There is evidence that high wages, coupled with investment subsidies, channeled investment flows heavily into labor saving equipment. This tendency is clearly visible in the manufacturing sector. Katja Gerling (2002) shows that investment into capital intensive sectors had a much larger share in East Germany than in West Germany, whereas the opposite was the case for skilled-laborintensive sectors.

\begin{tabular}{|c|c|c|}
\hline Sectors $^{28}$ & East Germany & West Germany \\
\hline Capital-intensive & $60 \%$ & $45 \%$ \\
\hline Skilled-Labor-intensive & $26 \%$ & $39 \%$ \\
\hline Unskilled-Labor-intensive & $14 \%$ & $16 \%$ \\
\hline
\end{tabular}

\footnotetext{
${ }^{26}$ Defined as number of people in the age group from 15 to 64 .

${ }^{27}$ Only a small part of the stronger reduction in East Germany can be explained by the inner German migration. A bigger proportion is due to a more pronounced immigration of foreigners to West Germany (and a lower birth rate in East Germany). We conclude that better long run perspectives render West Germany more attractive.

${ }^{28}$ Structure of investment in the manufacturing sector in East and West Germany according to industry aggregates, 1991-1999, for companies with more than 20 employees. Source: Gerling (2002), p. 41.
} 


\section{Table 2: Sectoral Investment}

Table 3 shows that the capital intensities (defined as capital stock divided by the number of employees) in the industry are bigger in East Germany than in West Germany. This phenomenon is even more pronounced when excluding the construction sector (see e.g. Sachverständigenrat, 2004, p. 311).

\begin{tabular}{||l||l||l||}
\hline \hline Capital Stock $^{29}$ & East Germany & West Germany \\
\hline \hline Year 1995 & 98 & 109 \\
\hline \hline Year 1999 & 125 & 124 \\
\hline \hline Year 2002 & 153 & 132 \\
\hline \hline
\end{tabular}

Table 3: Industrial Capital Intensities

The "wrong" capital-skills trap: Hans-Werner Sinn (1995) argues that the enormous investment subsidies have created a negative cost of capital in East Germany. Thus, capital was not only a factor of production, but also an economic good. Even if the cost of capital was negative in some cases, on average profitable projects were chosen. Nevertheless, the return on capital in East Germany was significantly lower in East Germany than in West Germany during the nineties. Margarethe Quehenberger (2000, p. 127) estimates that on average it was 5\% (15\%) from 1991 to 1998 in East (West) Germany and 8\% (16\%) from 1995 to 1998.

Besides generous investment subsidies there are many other institutional reasons for the creation of "wrong" capital: Sinn (1995) writes e.g. that generous depreciation rules were not helpful for founders of new firms, since they usually do not have any other substantial sources of income, which they could use to write-off their losses. Furthermore, much of the East German investment was not flowing into productive assets. Instead it was channeled into private building activity, stimulated by high wages (causing a boost in demand for rental housing) and the investment subsidies (ensuring low production costs), see e.g. Sinn (1995).

The nontradable trap: While prices in the service sector (which contains a big part of the non-tradable sector) have risen by almost 50\% from 1991 to 2001, the price increase in the manufacturing sector (excluding construction) was only $13 \% .{ }^{30}$ Manufacturing comprises a much smaller share of total employment in East Germany than in West Germany or in the Eastern European transition countries (see e.g. Quehenberger, 2000, p. 131, and Statistische Ämter des Bundes und der Länder, 2005).

\footnotetext{
${ }^{29}$ Industrial capital intensities for East and West Germany (excluding Berlin entirely), defined as capital stock in thousand Euro per employee. Source: Statistische Ämter des Bundes und der Länder (2005), own calculations.

${ }^{30}$ Source: Statistisches Bundesamt.
} 


\section{Calibration}

\subsection{Employment, Hiring and Firing Rates}

We now calibrate the model of Section 2 to provide a rough picture of how, quantitatively, various elements of the "caring hand" can influence East German employment. We begin by predicting the East German employment path, based on our employment dynamics function (3), the hiring rate (2), and the firing rate (1), as well as actual labor costs, productivity, firing costs, and unemployment benefits from 1991 to 2004 . (Source: Statistische Ämter des Bundes und der Länder, 2005). Real productivity ( $a$, gross value added per worker) in 2004 was about $€ 36,000$ and real wages $(w$, measured as real labor costs) were about $€ 22,000$. (All estimates are divided by the German GDP deflator, base year 1991.)

We interpret actual labor costs as embodying the outcome of the combination of wage bargaining forms - bargaining by proxy and self-sufficient bargaining - that have occurred in East Germany. Thus our predicted employment path is viewed as the outcome of this bargaining combination. Discrepancies between our predictions and the actual employment time series we then interpret a consonant with the existence of traps, providing indirect evidence of the cumulative size of these traps.

To derive the hiring and firing rates, we begin by considering a modified form of the firm's profit function:

$$
\Pi_{t}=-\alpha^{t} \varepsilon+a_{t}-w_{t}-\phi_{t+1} \delta f_{t+1}+\left(1-\phi_{t+1}\right) \delta E_{t}\left[\Pi_{t+1}\right]
$$

where we now explicitly take productivity growth into account. We divide time into the sample period (1991-2004) and post-2004 (the "long run"). The operating cost $\varepsilon$ is assumed to grow at 2 percent per annum over both subperiods $(\alpha=1.02)$. We use the actual productivity and wage numbers from 1991 to 2004 and we assume that in the long-run the productivity and all real costs (the wage, the hiring and firing costs, and the operating $\operatorname{cost} \varepsilon$ ) all grow at the same rate.

In the current period $t$, the profit is $\left(-\alpha^{t} \varepsilon+a_{t}-w_{t}\right)$. With probability $\phi_{t+1}$ the worker is fired at the beginning of the subsequent period and the firm has to pay the firing costs $f_{t+1}$, which are discounted $(\delta)$ at rate $3 \% .{ }^{31}$ With probability $\left(1-\phi_{t+1}\right)$ the worker is retained and thus the firm earns the expected profit $E_{t}\left[\Pi_{t+1}\right]$.

Firing costs $\left(f_{t}\right)$ are set to $60 \%$ of labor costs. ${ }^{32}$ We set the hiring costs $\left(h_{t}\right)$ to $10 \%$ of labor costs (see Yu-Fu Chen and Michael Funke, 2003). The replacement ratio

\footnotetext{
${ }^{31}$ This is the average real interest rate over the whole observation period, calculated as the yearly money market interest rate minus the inflation rate (using the GDP deflator). Source: International Financial Statistics, International Monetary Fund.

${ }^{32}$ The numbers are similar to evidence from Christian Grund (2003) who writes that the severance payment for collectively dismissed workers in Germany is 8500 Euro, while it is 7000 Euro for individidually dismissed person. Tenure and the wage level are the most important determinants.
} 
(of unemployment benefits to wages) is set at $60 \% .^{33}$ In practice, after being fired unemployment benefits generally amount to $60 \%^{34}$ of the last net income during a first stage. ${ }^{35}$

In this context, we also derive a time path of wages under self-sufficient bargaining. For this purpose, we first derive the annual West German bargaining strength parameter $\mu_{t}$ for each year from the wage eq. (5), using annual West German data on $\widehat{w}_{t}, \widehat{b}_{t}, \widehat{a}_{t}$, and $\widehat{f}_{t}$; then we assume the same $\mu_{t}$ for East Germany, and derive the East German wage $w_{t}$, using annual East German data on $b_{t}, a_{t}$, and $f_{t}$.

The firm, knowing the current period's operating costs, fires a worker in period $t$ if $\Pi_{t}<-f_{t}$ and it hires if $\Pi_{t}>h_{t}$. Thus, we obtain the following two implicit functions:

$$
\phi_{t}=1-\Gamma\left(\begin{array}{c}
\frac{1}{\alpha^{t}}\left(a_{t}-w_{t}\right)+\frac{1}{\alpha^{t}} f_{t}- \\
\frac{1}{\alpha^{t}} \delta \phi_{t+1} f_{t+1}+\frac{1}{\alpha^{t}} \delta\left(1-\phi_{t+1}\right) E_{t}\left[\Pi_{t+1}\right]
\end{array}\right),
$$

and

$$
\eta_{t}=\Gamma\left(\begin{array}{c}
\frac{1}{\alpha^{t}}\left(a_{t}-w_{t}\right)-\frac{1}{\alpha^{t}} h_{t}- \\
\frac{1}{\alpha^{t}} \delta \phi_{t+1} f_{t+1}+\frac{1}{\alpha^{t}} \delta\left(1-\phi_{t+1}\right) E_{t}\left[\Pi_{t+1}\right]
\end{array}\right)
$$

We linearize the firing and hiring rates (for technical details, see Appendix) with a first order Taylor expansion and obtain:

$$
\begin{aligned}
\phi_{t}= & \phi_{0}-\frac{1}{\alpha^{t}} \Gamma_{0}^{\prime}\left[\left(a_{t}-w_{t}\right)-\left(a_{t, 0}-w_{t, 0}\right)\right] \\
& -\frac{1}{\alpha^{t}} \Gamma_{0}^{\prime}\left[\left(f_{t}-f_{t, 0}\right)\right]+\frac{1}{\alpha^{t}} \delta \phi_{0} \Gamma^{\prime}{ }_{0}\left(f_{t+1}-f_{t+1,0}\right) \\
& -\delta \frac{1}{\alpha^{t}}\left(1-\phi_{0}\right) \Gamma_{0}^{\prime}\left(E_{t}\left[\Pi_{t+1}\right]-E_{t, 0}\left[\Pi_{t+1}\right]\right),
\end{aligned}
$$

and

\footnotetext{
${ }^{33}$ In 2002 the net replacement ratio of a person (without children) with the average production worker's salary was between 54 and $85 \%$ (depending on the family status) according to the OECD (2004, p. 95).

${ }^{34} 67 \%$ with children.

${ }^{35}$ The German unemployment benefit system differentiates between two stages. Roughly speaking, everyone who was at least employed (and insured in the social security system) for twelve months during the last three years is in a first stage eligible for "Arbeitslosengeld I" (usually for half a year to a year, with an exception for older people). In the second stage unemployed can obtain "Arbeitslosengeld II" (lower level of benefits), but have to prove their neediness.
} 


$$
\begin{aligned}
\eta_{t}= & \eta_{0}+\frac{1}{\alpha^{t}} \Gamma_{0}^{\prime}\left[\left(a_{t}-w_{t}\right)-\left(a_{t, 0}-w_{t, 0}\right)\right] \\
& -\frac{1}{\alpha^{t}} \Gamma_{0}^{\prime}\left(h_{t}-h_{t, 0}\right)-\frac{1}{\alpha^{t}} \delta \phi_{0} \Gamma_{0}^{\prime}\left(f_{t+1}-f_{t+1,0}\right) \\
& +\left(1-\phi_{0}\right) \frac{1}{\alpha^{t}} \delta \Gamma_{0}^{\prime}\left(E_{t}\left[\Pi_{t+1}\right]-E_{t, 0}\left[\Pi_{t+1}\right]\right) .
\end{aligned}
$$

where variables with a subscript 0 are at the reference point, around which we linearize. We choose the year 2004 for self-sufficient bargaining to be the reference point for our first order Taylor expansion. Thus, $E_{t, 0}\left[\Pi_{t+1}\right]$ would be the expected future profit in period $t$ if all variables trended along a $2 \%$ through the anchor point in 2004.

Since we assume that the productivity, the wage, and hiring and firing costs, and operating costs (all in real terms) grow at $2 \%$ in the long-run, hiring and firing rates are constant in the long-run. From 1991 to 2004, firing and hiring rates would not change if $a, w, f$, and $X$ would all grow along the $2 \%$. From the previous firing and hiring rate equations, it thus follows that $E_{t-1,0}\left[\Pi_{t}\right]=\frac{1}{\alpha} E_{t, 0}\left[\Pi_{t+1}\right]{ }^{36}$

We let our predicted $(\mathrm{P})$ hiring and firing rates, based on the actual data, ${ }^{37}$ be $\eta_{2004, P}=0.57$ and $\phi_{2004, P}=0.13$ in 2004, respectively. Furthermore, we assume that the predicted wage path converges to the self-sufficient (SS) bargaining wage path within ten years. ${ }^{38}$ In other words, the hiring and firing rates for self-sufficient bargaining in 2004 are the same as the predicted ones in 2014. Since we do not know the hiring and firing rate under self-sufficient bargaining in 2004 (anchor point), we set the values $\eta_{2004, S S}$ and $\phi_{2004, S S}$ in such a way that we obtain the expected values $\left(\eta_{2004, P}\right.$ and $\left.\phi_{2004, P}\right)$ for the prediction. All previous values are calculated recursively, based on the linearized model, under the assumption of perfect foresight over the entire sample period.

\subsection{Migration}

We endogenize migration by regressing the East German labor market growth due to migration on the derived present value differentials ${ }^{39}$ of incomes between East and West, and use the estimated coefficients for predictions in the policy exercises. In particular, we proceed along the following lines.

\footnotetext{
${ }^{36}$ The same is true for $\left(a_{t, 0}-w_{t, 0}\right), f_{t, 0}$, and $h_{t, 0}$.

${ }^{37}$ The estimated average risk of unemployment given employment is about 0.08 for West Germany (Ralf Wilke, 2004). Under a steady state unemployment rate of $10 \%$ the firing rate of $8 \%$ corresponds to a hiring rate of $72 \%$ in our model. The duration of unemployment was 35 weeks in West Germany and 44 weeks in East Germany in 2004 (Statistisches Bundesamt, 2005). Thus we set the hiring rate to $57 \%$ in East Germany. Consistent with a steady state unemployment rate of $18 \%$, the firing rate is set to $13 \%$.

${ }^{38}$ The wages under the prediction are linearly adjusted to the self-sufficient value in 2014 .

${ }^{39}$ Based on our model predictions.
} 
The East German workforce (employed plus unemployed people) is about $50 \%$ of the population. ${ }^{40}$ To generate the actual effect of migration on the workforce $\left(m_{t}\right)$ we multiply the actual number of migrants by 0.5 and divide it by the workforce.

For the calibration we once again modify equation (4) to take account of productivity growth. Specifically, we assume that the migration costs of the marginal migrant $\kappa\left(m_{j t}\right), j=i, o$ grow at the same rate as productivity and all the firm's costs in the long run (viz., 2 percent). ${ }^{41}$ Thus migration is $m_{j, t}=\kappa^{-1}\left(\frac{K_{j}}{\alpha^{t}}\right)$, so that the migration function becomes

$$
m_{t}=\kappa^{-1}\left(\frac{\widehat{V}_{o, t}-V_{i, t}}{\alpha^{t}}\right)+\kappa^{-1}\left(\frac{\widehat{V}_{o, t}-V_{o, t}}{\alpha^{t}}\right)
$$

Next, we estimate the equation $m_{t}=\beta_{1}+\beta_{2}\left[\left(2 \widehat{V}_{o, t}-V_{i, t}-V_{o, t}\right) / \alpha^{t}\right]$, through ordinary least squares. We use the estimated coefficients (denoted by the tilde $\left(^{\sim}\right)$ ) $\tilde{\beta}_{1}$ and $\tilde{\beta}_{2}$ to obtain $\tilde{m}_{t}$, which is the estimated effect of migration on the labor force growth.

Naturally, the growth of the labor force cannot be entirely explained by migration, since other factors such as population growth, active labor market policies or early retirement schemes played a important roles (see e.g. Fuchs and Weber, 2005, or DIW Berlin et al., 2002), and these latter factors are not explained in our model. Thus, we define an exogenous residual $\left(g_{t, x}\right)$, which is the difference of the actual labor force growth in the respective year $\left(g_{t, a}\right)$ minus the effects the calculated effects of migration on the labor force $\left(m_{t, m}\right)$, thus reading: $g_{t, x}=g_{t, a}-m_{t, m}$.

Consequently, the labor force growth rate under different policy exercises is predicted as: $g_{t, a}=\tilde{m}_{t, m}+g_{t, x}$, where only the migration effects vary, which is calculated based on the estimated coefficients $\tilde{\beta}_{1}$ and $\tilde{\beta}_{2}{ }^{42}$, and the exogenous component stays constant.

The calculated hiring and hiring rates and the labor market growth are then substituted into the employment dynamics curve (3), in order to generate our predicted path of employment rates as well as the path under self-sufficient bargaining.

\subsection{Results}

Fig. (7) ${ }^{43}$ shows the time series of the actual employment development and the predicted employment. Note that our model predicts an improvement of employment

\footnotetext{
${ }^{40}$ Sources: Bundesagentur für Arbeit (2006) and Statistisches Bundesamt (2005).

${ }^{41}$ Omitting this assumption would mean that East Germany would be completely de-populated when East and West Germany grow at the same rate since the absolute present value differential would grow without recess (because of the time trend).

${ }^{42}$ The estimated values for $\tilde{\beta}_{1}$ and $\tilde{\beta}_{2}$ can be found in the Appendix.

${ }^{43}$ Note that employment rates are shown in figure (1). The employment path in figure (7) is derived from the employment rates and the labor force growth rate.
} 


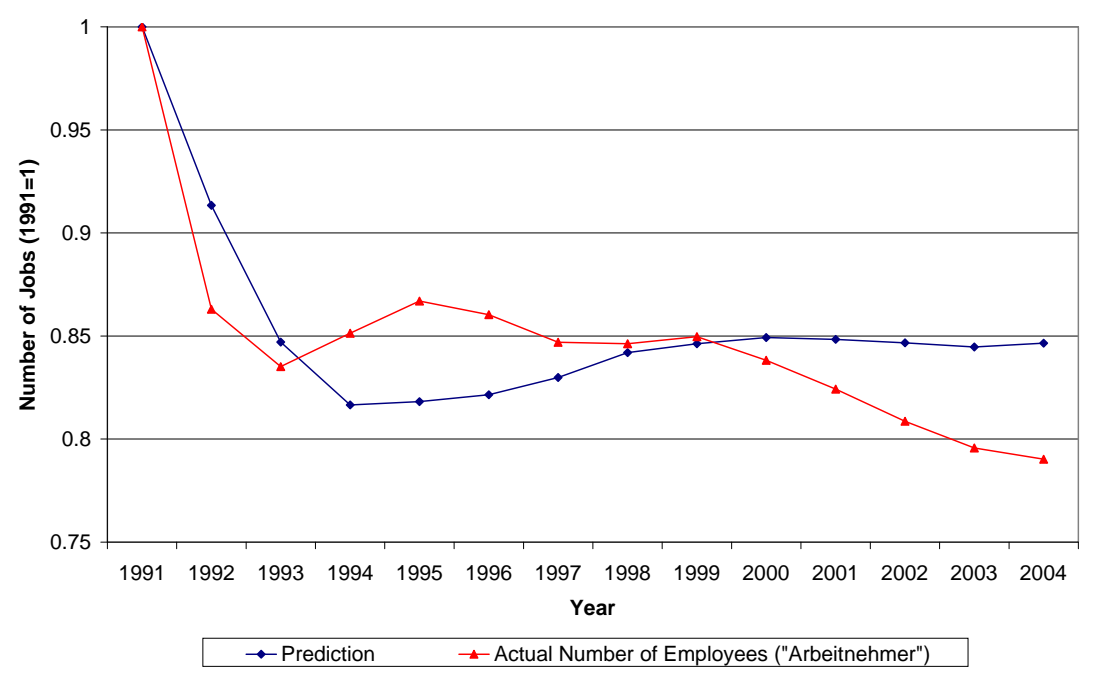

Figure 7: Development of the number of employees (1991=1).

since the mid-nineties, whereas the actual numbers do not do so. This discrepancy could be captured by our trap model.

Figure (8) shows the prediction of employment rate under different policy exercises and the actual development (excluding job creation programs, which cannot be captured by our model). ${ }^{44}$

Observe that the bargaining by proxy curve tends towards the self-sufficient bargaining prediction, in agreement with our observation that self-sufficient bargaining is becoming increasingly pervasive in East Germany.

In this context, we now consider the effects of two policies:

1. reducing the ratio of firing costs to wages by $5 \%$ and

2. reducing the replacement ratio (of unemployment benefits to wages) by $5 \%$.

We examine these policies under self-sufficient bargaining. For this purpose, we linearize equation (1) with respect to all variables determining future profits $E_{t}\left[\Pi_{t+1}\right]$. See Appendix for technical details.

Fig. (8) tells an interesting story about various ingredients of the "caring hand." It shows that if the firing cost ratio and the replacement ratio would both have been reduced by $5 \%$, the employment path ("SS barg $+f$ and $r r$ reduction" in the

\footnotetext{
${ }^{44}$ It is worth noting that differences to figure (7) arise because of the exogenous growth of the East German labor force. The East German labor force (excluding Berlin), defined as employed plus unemployed, grew from 1995 to 1997. Consequently, the predicted increased number of jobs is not visible in the predicted employment rate. The actual employment rates in figure (8) include Berlin, which enables us to exclude job creation programs from the data.
} 


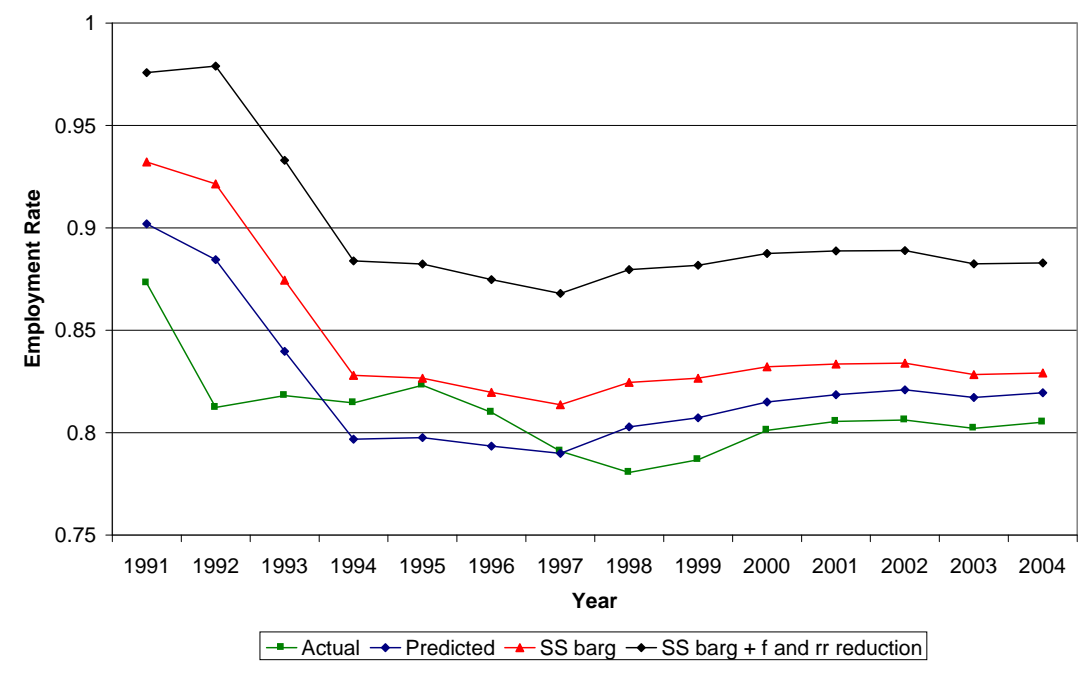

Figure 8: Employment Rates under Different Policies

figure) would have risen substantially above the employment rates under self-sufficient bargaining alone, which in turn is substantially above the actual employment path.

These two policies are complementary in our model. For example, a reduction in the replacement ratio reduces the wage and thereby reduces the firing rate; this gives more leverage to the employment-promoting influence of a reduced firing cost (via wage reduction), since this reduced firing cost and wage is paid over a longer expected job tenure. Such policy complementarities, along with the migration induced by the policies, account for the magnitude of the employment effects.

Including labor market traps in our calibration would of course imply that, in the absence of sufficiently large positive shocks, employment rates would display little tendency to recover from their post-unification trough. In this context, our analysis implies that East German employment rates would have been higher over the past decade if the initial downturn in employment had been less encumbered by the West German "caring hand."

\section{Concluding Thoughts}

This paper provides a sober assessment of the East German labor market problem, suggesting that this problem has been exacerbated by various forms of "care" that the East has received from the West: support in bargaining, unemployment benefits, and job security provisions, in particular.

Our analysis also implies that it is pointless to wait for the problem to disappear of its own accord. In the absence of fundamental policy reform, the damage is permanent, not temporary. The reasons are that (i) even once the East Germans gain 
control over their own wages, the resulting wage negotiations - based on generous unemployment benefits and job security provisions - will still generate wages that are high relative to productivity and (ii) the resulting unemployment can become perpetuated through various labor-market traps. Without a policy reform package that is "deep" (radically improves employment incentives) and "broad" (a range of complementary measures), ${ }^{45}$ East Germany is likely to remain dependent on the caring hand that cripples.

\footnotetext{
${ }^{45}$ See, for example, David Coe and Dennis J. Snower (1997).
} 


\section{References}

Bonin, Holger, and Zimmermann, Klaus. "The Post-Unification German Labor Market." IZA Discussion Paper, No. 185, August 2000.

Brücker, Herbert, and Trübswetter, Parvati. "Do the Best Go West? An Analysis of the Self-Selection of Employed East-West-Migrants in Germany." DIW Discussion Paper, No. 396, February 2004.

Büchel, Felix, and Schwarze, Johannes. "Die Migration von Ost- nach Westdeutschland - Absicht und Realisierung. Ein sequentielles Probitmodell mit Kontrolle unbeobachtbarer Heterogenität." Mitteilungen aus der Arbeitsmarkt- und Berufsforschung, 1/1994, pp. 43-52.

Bundesagentur für Arbeit. "Arbeitslose und Arbeitslosenquoten." Online Source: www1.arbeitsamt.de/hst/services/ statistik/aktuell/iiia4/zr_alob.xls, January 2006.

Burda, Michael, and Hunt, Jennifer. "From Reunification to Economic Integration: Productivity and the Labor Market." Brookings Papers on Economic Activity, 2001, (2), pp. 1-71.

Burda, Michael, Härdle, Wolfgang, Müller, Marlene, and Werwatz, Axel. "Semiparametric Analysis of German East-West Migration Intentions: Facts and Theory." Journal of Applied Econometrics, Vol. 13, No. 5, (Sept.-Oct., 1998), pp. 525-541.

Burda, Michael. "Ist das Maß halb leer, halb voll oder einfach voll? Die volkswirtschaftlichen Perspektiven der neuen Bundesländer." Antrittsvorlesung, Humboldt Universität zu Berlin, 26 Oktober 1994.

Burda, Michael. "The Determinants of East-West German Migration. Some First Results." European Economic Review, 37, 1993, pp. 452-461.

Burda, Michael, and Funke, Michael. "German Trade Unions After Unification - Third Degree Wage Discriminating Monopolists." Weltwirtschaftliches Archiv, 129, 1993, pp. 537-560.

Buslei, Hermann, and Steiner, Viktor. "Beschäftigungseffekt von Lohnsubventionen im Niedriglohnbereich." ZEW-Wirtschaftsanalysen, Baden-Baden, 1999.

Chen, Yu-Fu, and Funke, Michael. "Labour Demand in Germany: An Assessment of Non-Wage Labour Costs." CESifo Working Paper, No. 952, May 2003.

Coe, David, and Snower, Dennis J. "Policy Complementarities: The Case for Fundamental Labor Market Reform." IMF Staff Papers, March 1997, 44 (1), pp. $1-35$.

Czada, Georg. "Der Vereinigungsprozeß - Wandel der externen und internen Konstitutionsbedingungen des westdeutschen Modells." in: Simonis, Georg (ed.), 1998, "Deutschland nach der Wende." Opladen: Leske+Budrich, pp. 55-86.

Deutsches Institut für Wirtschaftsforschung (DIW Berlin), Institut für Weltwirtschaft an der Universität Kiel (IfW), Institut für Arbeitsmarktund Berufsforschung (IAB), Zentrum für Europäische Wirtschaftsforschung 
(ZEW). "Fortschrittsbericht wirtschaftswissenschaftlicher Institute über die wirtschaftliche Entwciklung in Ostdeutschland." Forschungsauftrag des Bundesministeriums der Finanzen, Halle, 17 June 2002.

Deutsches Institut für Wirtschaftsforschung (DIW). "Wochenbericht 43/94." Berlin, 27 October 1994.

Deutsches Institut für Wirtschaftsforschung (DIW). "Wochenbericht 1819/93." Berlin, 6 May 1993.

Falk, Martin, and Köbel, Betrand. "A Dynamic Heterogeneous Labour Demand Model for German Manufacturing." Applied Economics, 33, 2001, pp. 339348.

Fitzroy, Felix, and Funke, Michael. "Skills, Wages and Employment in East and West Germany." Regional Studies, Vol. 32.5, 1996, pp. 459-467.

Flaig, Gebhard, and Steiner, Viktor. "Stability and Dynamic Properties of Labour Demand in West German Manufacturing." Oxford Bulletin of Economics and Statistics 51, 1989, pp. 395-412.

Franz, Wolfgang, and König, Heinz. "The Nature and Causes of Unemployment in the Federal Republic of Germany since the 1970s: An Empirical Investigation." Economica, 53, 1989, pp.219-244.

Fuchs, Johann, and Weber, Brigitte. "Neuschätzung der Stillen Reserve und des Erwerbspersonenpotenzials für Ostdeutschland (einschl. Berlin-Ost)." IAB Forschungsbericht, Nr. 18/2005.

Gerling, Katja. "Subsidization and Structural Change in Eastern Germany." Kiel Studies, Springer, 2002.

Grund, Christian, "Severance Payments for Dismissed Workers in Germany." IZA Discussion Paper, No. 875, September 2003.

Heitger, Bernhard. "Minimum Wages and Employment: The Case of German Unification." Kiel Institute for World Economics, Kiel Working Paper, No. 1045, May 2001.

Hunt, Jennifer. "Why do People Still Live in East Germany?" NBER Working Paper, No. 7564, February 2000.

Institut für Arbeitsmarkt- und Berufsforschung (IAB). "Dramatischer Rückgang der Bevölkerung im Osten." IAB Kurzbericht, 28 October 2005.

International Labour Organization (ILO). "World Employment Report 200405. Employment, Productivity and Poverty Reduction." 7 December 2004, Geneva.

Klodt, Henning. "Industrial Policy and the East German Productivity Puzzle." German Economic Review, 2000, 1 (3), pp. 315-333.

Kohaut, Susanne, and Schnabel, Claus. "Tarifverträge - nein danke!? Einflussfaktoren der Tarifbindung west- und ostdeutscher Betriebe" Friedrich-AlexanderUniversität Erlangen-Nürnberg, Discussion Papers, No. 8, December 2001.

Kraft, Kornelius. "Lohnflexibilität und Beschäftigung in der bundesdeutschen Industrie." Jahrbücher für Nationalökonomie und Statistik, 208 (3), 1991, pp. 239253. 
Lehmann, Harald, Ludwig, Udo, and Ragnitz, Joachim. "Originäre Wirtschaftskraft der neuen Länder noch schwächer als bislang angenommen." Wirtschaft im Wandel, 5/2005, 25 May 2005, pp. 134-145.

Organisation for Economic Co-operation and Development (OECD). "Benefits and Wages. OECD Indicators." Paris, 2004.

Ragnitz, Joachim. "Wie hoch sind die Transferleistungen für die neuen Länder?" IWH-Pressemitteilung, 21/2003, 27 Oktober 2003.

Riphahn, Regina, Thalmeier, Anja, and Zimmermann, Klaus. "Schaffung von Arbeitsplätzen für Geringqualifizierte." IZA-Research Report No. 2, Bonn, July 1999.

Quehenberger, Margarethe. "Ten Years After: Eastern Germany's Convergence at a Halt?" EIB Papers, 5 (1), 2000, pp. 117-136.

Sachverständigenrat zur Beurteilung der gesamtwirtschaftlichen Lage. "Jahresgutachten 2004/05. Erfolge im Ausland - Herausforderungen im Inland." Wiesbaden, 2004.

Schnabel, Claus. "Gewerkschaften und Arbeitgeberverbände: Organisationsgrade, Tarifbindung und Einflüsse auf Löhne und Beschäftigung." Friedrich-AlexanderUniversität Erlangen-Nürnberg, Discussion Papers, No. 34, May 2005.

Schmidt, Christoph. "Persistence and the German Unemployment Problem: Empirical Evidence on German Labour Market Flows." CEPR Discussion Paper, No. 2057, January 1999.

Schröder, Wolfgang. "Industrielle Beziehungen in Ostdeutschland: Zwischen Eigensinn und Paternalismus." Veröffentlichungsreihe der Abteilung Institutionen und sozialer Wandel des Forschungsschwerpunkts Sozialer Wandel, Institutionen und Vermittungsprozesses des Wissenschaftszentrums Berlin für Sozialforschung, FS III 00-203, May 2000.

Sinn, Hans-Werner. "Germany's Economic Unification: An Assessment after Ten Years." Review of International Economics, 2002, 10 (1), pp. 113-128.

Sinn, Hans-Werner. "Staggering Along: Wages Policy and Investment Support in East Germany." Economics of Transition, Vol. 3 (4), 1995, pp. 403-426.

Smolny, Werner. "Produktivitätsanpassung in Ostdeutschland." Jahrbücher für Nationalökonomie und Statistik 223/2, March 2003, pp. 239-254.

Stark, Ernst, and Jänsch, Günter. "Faktoreinsatzverhalten im verarbeitenden Gewerbe. Eine sektorale Analyse unter Verwendung eines Translog-Modell." DIW Vierteljahreshefte zur Wirtschaftsforschung, 1/2, 1988, pp. 79-95.

Statistische Ämter des Bundes und der Länder. "Volkswirtschaftliche Gesamtrechnungen der Länder." Online Source: http://www.vgrdl.de/Arbeitskreis_VGR/, date of computation: February 2005.

Statistisches Bundesamt. "Datenreport 2004." Bonn, second updated edition, 2005.

Trabert, Lioba, Dreger, Christian, Kempe, Wolfram, and Kolb, Jürgen. "Gutachten des Instituts für Wirtschaftsforschung Halle (IWH)." in: Ministerium für 
Arbeit, Frauen, Gesundheit und Soziales des Landes Sachsen-Anhalt. "Kombilohn in Sachsen-Anhalt." Forschungsbeiträge zum Arbeitsmarkt in Sachsen-Anhalt, 12, 1998.

Wilke, Ralf. "New Estimates of the Duration and Risk of Unemployment for West Germany." Zentrum für Europäische Wirtschaftsforschung, Discussion Paper, No. 04-26, March 2004.

Zimmermann, Klaus, and Bauer, Thomas. "Integrating the East: The Labor Market Effects of Immigration." in: Black, Stanley. "Europe's Economy Looks East: Implications for Germany and the European Union." Cambridge University Press, 1997, pp. 269-306. 


\section{Appendix}

\subsection{Further Empirical Evidence}

We borrow an example from Michael Burda (1994, p. 8) which nicely illustrates what happened in the dawn of transition (from 1990 to 1993), by comparing some numbers for East Germany and Czech Republic:

\begin{tabular}{||l||l||l||l||l||l||l||}
\hline \hline Changes (1990-1993) & GDP & Prices & Wages $^{46}$ & Employment & UE $^{47}$ & CAD $^{48}$ \\
\hline \hline East Germany & $-22 \%$ & $+34 \%$ & $62 \%$ & $-34 \%$ & $16 \%$ & $77 \%$ \\
\hline \hline Czech Republic & $-21 \%$ & $+110 \%$ & $-18 \%$ & $-8 \%$ & $4 \%$ & $1 \%$ \\
\hline \hline
\end{tabular}

Table 4: Comparison of Czech Republic and East Germany

East Germans enjoyed significant real wage increases due to bargaining by proxy and the introduction of the Deutsch Mark. The latter served as an anchor and prevented prices to increase by the same magnitude as in other Eastern European countries. Nevertheless, there were considerable price increases in the non-tradable sector. The drop in real GDP was similar in East Germany and in Czech Republic. East Germans did not perform worse because they received massive consumption transfers and investments into the infrastructure, which was by the most part paid by the West. Transfers boosted the non-tradable sector, especially the construction industry, where a boom-bust cycle was initiated whose consequences can still be seen today (the construction industry in East Germany is still shrinking).

\subsection{Theoretical Derivations: Bargaining by Proxy}

Since the present value of the worker's surplus is time-invariant, the present value of the firm's surplus is time-invariant was well. Thus the solution of the Nash optimization is time-invariant. Thus,

$$
\widehat{n}_{t}=\widehat{n}
$$

\footnotetext{
${ }^{46}$ Real wage per employee.

${ }^{47}$ Unemployment rate in 1993.

${ }^{48}$ Current account deficit in percent of GDP (in 1993).
} 
Then the present values from equations (6) and (7) can be expressed as

$$
\begin{aligned}
\Lambda_{w} & =\left(\hat{y}_{i}-\hat{y}_{o}\right)\left(\sum_{t=0}^{\infty} \delta^{t} \hat{n}_{t}\right)=\left(\hat{y}_{i}-\hat{y}_{o}\right) \widehat{n}\left(\sum_{t=0}^{\infty} \delta^{t}\right) \\
& =\left(\hat{y}_{i}-\hat{y}_{o}\right) \widehat{n} \frac{1}{1-\delta} \\
\Lambda_{f} & =\sum_{j=0}^{\infty} \delta^{t}\left(\widehat{\sigma}_{a}-\widehat{\sigma}_{n} \hat{n}_{t+j}\right) \\
& =\frac{\widehat{\sigma}_{a}}{1-\delta}-\frac{\widehat{\sigma}_{n} \widehat{n}}{1-\delta}
\end{aligned}
$$

Inserting these into the Nash equation:

$$
\mu\left(\Lambda_{w}\right)^{-1} \frac{\partial \Lambda_{w}}{\partial n_{0}}\left(\Lambda_{f}\right)+(1-\mu) \frac{\partial \Lambda_{f}}{\partial n_{0}}=0
$$

After some re-formulation we obtain:

$$
\widehat{n}=\mu \frac{\widehat{\sigma}_{a}}{\widehat{\sigma}_{n}}
$$

Thus:

$$
\widehat{n}=\mu \frac{\widehat{a}-\widehat{w}-\widehat{h} \widehat{\eta}+\widehat{f}}{\widehat{f} \widehat{\phi}-\widehat{h} \widehat{\eta}}
$$

The greater the West German productivity $\hat{a}$ and the greater the workers' bargaining strength $\mu$, the greater is the West German target employment rate and the higher the East German wage will be set. The lower the migration costs $\kappa$, the higher will be the East German wage corresponding to a given West German target employment rate. In this way our model shows why the East German labor market suffered on account of a purported "strength" of the West German labor market high productivity - and purported "advantages" of the East Germans - the ability to migrate to the wealthy West and increased bargaining power bestowed by their Western counterparts. 


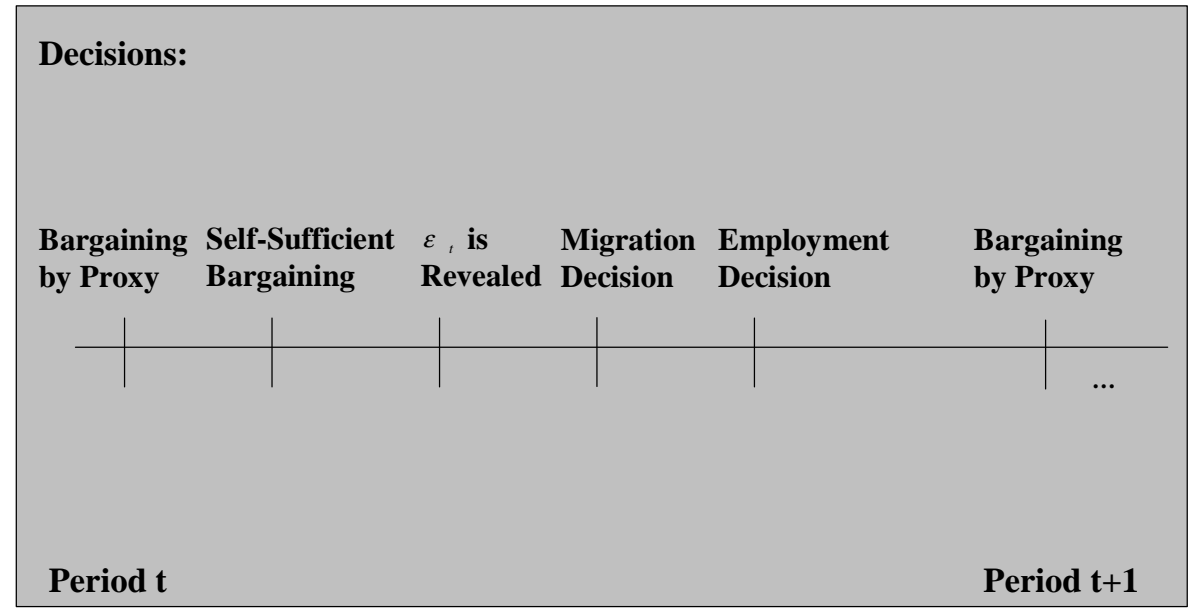

Time Axis

Figure 9: Sequencing of Decisions

\subsection{Detailed Description of the Calibration}

\subsubsection{Hiring and Firing under Constant Growth Rates}

Sequencing of Decisions: There is an operating cost $\varepsilon_{t}$ that is a random variable, with a cumulative distribution $\Gamma\left(\varepsilon_{t}\right)$, which is normalized to zero and iid across workers and time. See figure (9) for an illustration of the sequencing.

Under bargaining by proxy, West German firms and workers bargain for the East German wage level. In sectors where self-sufficient bargaining prevails, East German firms and insiders bargain for their wage, as described in equation (5). We assume that insiders seek to maximize the utility of the representative insider (the median voter).

After the operating costs are revealed East Germans decide if they want to migrate, based on their present value of income. Finally, the employment decision is taken. If a firm hires a worker, it has to pay the operating cost $\varepsilon_{t}$. The current profit generated by the worker is $\pi_{t}=a_{t}-w_{t}-\varepsilon_{t}$.

Workers who are hired or not fired remain employed until the end of the period (the opposite is true for workers who are fired or not hired). At the beginning of the next period $(t+1)$, the same process starts again. 
Firing Rate: When the productivity, wages (labor costs) and firing costs trend all along the same constant time path and when this constant time path is equal to the trend of the operating costs, then the hiring and firing rates are constant (see theoretical part where we assumed a zero growth rate for simplicity). We assume that there are constant returns to labor.

Let the firing rate be $\phi$. In the initial period, the insider generates a profit of $a-w-\varepsilon$; if he is fired at the beginning of the next period (with probability $\phi$ ), then he generates a cost of $f$; if he is retained at the beginning of the next period (with probability $(1-\phi)$ ), then he generates an expected profit of $\alpha(a-w)$ (under the assumption that the wage and productivity grow at a rate $\alpha-1$, with $\alpha>1^{49}$ ). At the beginning of the third period, the probability of being retained is $(1-\phi)^{2}$, and the probability of being retained at the beginning of the second period but fired in the third is $(1-\phi) \phi$; and so on. Thus the present value of the profit generated by an insider is

$$
\begin{aligned}
& \Pi_{i}=(a-w)-\varepsilon+\left(\delta \alpha(1-\phi)(a-w)+(\alpha \delta)^{2}(1-\phi)^{2}(a-w)+\ldots\right) \\
&-\delta\left(\phi f+(1-\phi) \phi \alpha \delta f+(1-\phi)^{2} \phi \alpha^{2} \delta^{2} f+\ldots\right) \\
&=(a-w)-\varepsilon+\sum_{t=1}^{\infty}(\alpha \delta)^{t}(1-\phi)^{t}(a-w)-\delta \phi f \sum_{t=0}^{\infty}(\alpha \delta)^{t}(1-\phi)^{t} \\
&=-\varepsilon+\frac{a-w}{1-\alpha \delta(1-\phi)}-\frac{\delta \phi f}{1-\alpha \delta(1-\phi)} \\
& \Pi_{i}=-\varepsilon+\frac{(a-w)-\delta \phi f}{1-\alpha \delta(1-\phi)}
\end{aligned}
$$

where $\delta$ is the discount factor $(\delta<1)$.

A worker is fired when his present value of profit is less than $-f$ (the firing cost).

$$
\begin{aligned}
-\varepsilon+\frac{(a-w)-\delta \phi f}{1-\alpha \delta(1-\phi)} & <-f \\
\varepsilon & >\frac{(a-w)-\delta \phi f}{1-\alpha \delta(1-\phi)}+f \\
\varepsilon & >\frac{(a-w)}{1-\delta \alpha(1-\phi)}-\frac{\delta \phi f}{1-\delta \alpha(1-\phi)}+f \\
\varepsilon & >\frac{(a-w)+(1-\delta) f}{1-\alpha \delta(1-\phi)}
\end{aligned}
$$

Thus, the probability of being fired is:

\footnotetext{
${ }^{49}$ We set the infinite growth rate to $2 \%$. Thus $\alpha=1.02$.
} 


$$
\phi=1-\Gamma\left(\frac{(a-w)+(1-\delta) f}{1-\delta \alpha(1-\phi)}\right)
$$

Hiring Rate: A worker is hired at the beginning of the period if the expected profit is bigger than the hiring costs:

$$
\begin{aligned}
\pi & >h \\
-\varepsilon+\frac{(a-w)-\delta \phi f}{1-\alpha \delta(1-\phi)} & >h \\
\varepsilon & <\frac{(a-w)-\delta \phi f}{1-\alpha \delta(1-\phi)}-h
\end{aligned}
$$

Thus

$$
\eta=\Gamma\left(\frac{(a-w)-\delta \phi f}{1-\alpha \delta(1-\phi)}-h\right)
$$

\subsubsection{Time Varying Parameters}

Firing Rate: To control for the time trend in the data, we first of all deflated all productivity (defined as gross value added per employee) and labor cost (defined as gross wages plus additional social security payments of the employers) numbers (by dividing by the 1991 German GDP deflator). Furthermore, we assume that the distribution of the operating costs shifts along a $2 \%$ time trend, starting at $\alpha^{1} \varepsilon_{t}$ in 1991.

We assume for simplicity that companies expect wages, productivity and firing costs to trend along a constant $2 \%$ growth path from period 2004 onwards $(\alpha>1)$ for self sufficient bargaining, starting at their estimated 2004 value (see below for the calculation). The same is true for our prediction, based on actual values, from 2014 onwards when this path has converged to the self-sufficient bargaining path. We assume that the actual real wage in 2004 adjusts linearly to the self-sufficient real wage in 2014.

For the 1991 to 2004 values we assume perfect foresight. We use the 2004 value for self-sufficient bargaining as an anchor and calculate all other firing rates in the model with a first order Taylor series expansion with respect to this point. Furthermore the 2004 values for self-sufficient bargaining are set in such a way that the firing rate for predictions, based on the actual values, is $12.5 \%$ in 2004 and the hiring rate is $57 \%$ in 2004.

The expected present value of profits in 2005 for self-sufficient bargaining is equal to: 


$$
\begin{aligned}
& \Pi_{2005}= \alpha(a-w)-\varepsilon_{2005}+\alpha \sum_{t=1}^{\infty}(\alpha \delta)^{t}(1-\phi)^{t}(a-w)- \\
& \alpha \delta \phi f \sum_{t=0}^{\infty}(\alpha \delta)^{t}(1-\phi)^{t} \\
&=-\varepsilon_{2005}+\frac{\alpha(a-w)}{1-\delta \alpha(1-\phi)}-\frac{\alpha \delta \phi f}{1-\delta \alpha(1-\phi)} \\
& \Pi_{2005}=-\varepsilon_{2005}+\frac{\alpha[(a-w)-\delta \phi f]}{1-\delta \alpha(1-\phi-r)}
\end{aligned}
$$

Thus, firms expect the following profits for a worker in period $t-1$ (if he is retained):

$$
E_{2004}\left(\Pi_{2005}\right)=(1-\phi) \delta\left[\alpha \frac{[(a-w)-\delta \phi f]}{1-\alpha \delta(1-\phi)}\right]
$$

where $\phi$ is the infinite firing rate.

The profit in 2004 writes as follows:

$$
\Pi_{2004}=-\alpha^{14} \varepsilon+a_{2004}-w_{2004}-\phi \delta f+\delta(1-\phi)\left[\alpha \frac{[(a-w)-\phi f]}{1-\alpha \delta(1-\phi)}\right] .
$$

The firm has to pay the operating costs and earns the productivity minus the wage. If it does not retain the worker at the beginning of period $t+1$, it has to pay the firing cost. Otherwise it earns the expected future present value of this worker.

Letters without time subscripts denote the long-run values. Letters with time subscripts denote the numbers in the respective period.

Firms fire a workers at the beginning of 2004 if $\Pi_{2004}<-f_{2004}$.

$$
\begin{aligned}
\alpha^{14} \varepsilon> & a_{2004}-w_{2004}+f_{2004} \\
& -\delta \phi f+\delta(1-\phi)\left[\alpha \frac{[(a-w)-\phi f]}{1-\alpha \delta(1-\phi)}\right]
\end{aligned}
$$

Thus:

$$
\phi_{2004}=1-\Gamma\left(\begin{array}{c}
\frac{1}{\alpha^{14}}\left(a_{2004}-w_{2004}\right)+\frac{1}{\alpha^{14}} f_{2004} \\
-\frac{1}{\alpha^{14}} \delta \phi f+\delta \frac{1}{\alpha^{14}}(1-\phi)\left[\alpha \frac{[(a-w)-\phi f]}{1-\alpha(1-\phi)}\right]
\end{array}\right),
$$

In period 2004 the expected future present value in case of retention is defined as:

$$
E_{2004}\left(\Pi_{2005}\right)=\left[\alpha \frac{[(a-w)-\delta \phi f]}{1-\alpha \delta(1-\phi)}\right],
$$


In period 2003 it is:

$$
E_{2003}\left(\Pi_{2004}\right)=\left(\begin{array}{c}
a_{2004}-w_{2004}-\delta \phi f \\
+\delta(1-\phi)\left[\alpha \frac{[(a-w)-\delta \phi f]}{1-\alpha(1-\phi)}\right]
\end{array}\right)
$$

and so on.

Thus:

$$
\phi_{2004}=1-\Gamma\left(\begin{array}{c}
\frac{1}{\alpha^{14}}\left(a_{2004}-w_{2004}\right)+\frac{1}{\alpha^{14}} f_{2004} \\
-\frac{1}{\alpha^{14}} \delta \phi f+\delta(1-\phi) \frac{1}{\alpha^{14}} E_{2004}\left(\Pi_{2005}\right)
\end{array}\right),
$$

and one period before:

$$
\phi_{2003}=1-\Gamma\left(\begin{array}{c}
\frac{1}{\alpha^{13}}\left(a_{2003}-w_{2003}\right)+\frac{1}{\alpha^{13}} f_{2003} \\
-\frac{1}{\alpha^{13}} \delta \phi_{2004} f_{2004}+\delta\left(1-\phi_{2004}\right) \frac{1}{\alpha^{13}} E_{2003}\left(\Pi_{2004}\right)
\end{array}\right),
$$

or generally:

$$
\phi_{t}=1-\Gamma\left(\begin{array}{c}
\frac{1}{\alpha^{t}}\left(a_{t}-w_{t}\right)+\frac{1}{\alpha^{t}} f_{t} \\
-\frac{1}{\alpha^{t}} \delta \phi_{t+1} f_{t+1}+\frac{1}{\alpha^{t}} \delta\left(1-\phi_{t+1}\right) E_{t}\left(\Pi_{t+1}\right)
\end{array}\right) .
$$

We linearize the firing rate with respect to the anchor (which is the year 2004 under self-sufficient bargaining).

$$
\begin{aligned}
\phi_{t}= & \phi_{0}-\frac{1}{\alpha^{t}} \Gamma_{0}^{\prime}\left[\left(a_{t}-w_{t}\right)-\left(a_{t, 0}-w_{t, 0}\right)\right] \\
& -\frac{1}{\alpha^{t}} \Gamma_{0}^{\prime}\left[\left(f_{t}-f_{t, 0}\right)\right]+\frac{1}{\alpha^{t}} \delta \phi_{0} \Gamma_{0}^{\prime}\left(f_{t+1}-f_{t+1,0}\right) \\
& -\delta \frac{1}{\alpha^{t}}\left(1-\phi_{0}\right) \Gamma_{0}^{\prime}\left(E_{t}\left[\Pi_{t+1}\right]-E_{t, 0}\left[\Pi_{t+1}\right]\right)
\end{aligned}
$$

Remark that we detrend the anchor variables. In $t$, e.g. $a_{t-n, 0}=\left(\frac{1}{\alpha}\right)^{n} a_{t, 0}$. The reason is that there would be no change of the firing rate if all variables would just grow along their $2 \%$ trend per period.

Hiring Rate: The firm hires in 2004 if $\pi_{2004}>h_{2004}$.

$$
-\alpha^{14} \varepsilon_{2004}+a_{2004}-w_{2004}-\phi \delta \alpha f+\delta(1-\phi)\left[\alpha \frac{[(a-w)-\phi f]}{1-\alpha \delta(1-\phi)}\right]+h_{2004}>0
$$

The cumulative function for the hiring rate in period t-1 looks as follows:

$$
\eta_{2004}=\Gamma\left(\begin{array}{c}
\frac{1}{\alpha^{14}}\left(a_{2004}-w_{2004}\right)-\frac{1}{\alpha^{14}} h_{2004}+ \\
\frac{1}{\alpha^{14}} \delta \phi \alpha f+(1-\phi) \delta \frac{1}{\alpha^{14}} E_{2004}\left(\Pi_{2005}\right)
\end{array}\right),
$$


or generally speaking:

$$
\eta_{t}=\Gamma\left(\frac{1}{\alpha^{t}}\left(a_{t}-w_{t}\right)-\frac{1}{\alpha^{t}} h_{t}-\frac{1}{\alpha^{t}} \delta \phi_{t+1} f_{t+1}+\left(1-\phi_{t+1}\right) \delta \frac{1}{\alpha^{t}} E_{t}\left(\Pi_{t+1}\right)\right) .
$$

After linearizing, we obtain:

$$
\begin{aligned}
\eta_{t}= & \eta_{0}+\frac{1}{\alpha^{t}} \Gamma_{0}^{\prime}\left[\left(a_{t}-w_{t}\right)-\left(a_{t, 0}-w_{t, 0}\right)\right] \\
& -\frac{1}{\alpha^{t}} \Gamma_{0}^{\prime}\left(h_{t}-h_{t, 0}\right)-\frac{1}{\alpha^{t}} \delta \phi_{0} \Gamma_{0}^{\prime}\left(f_{t+1}-f_{t+1,0}\right) \\
& +\left(1-\phi_{0}\right) \frac{1}{\alpha^{t}} \delta \Gamma_{0}^{\prime}\left(E_{t}\left[\Pi_{t+1}\right]-E_{t, 0}\left[\Pi_{t+1}\right]\right)
\end{aligned}
$$

\subsubsection{Calculation of Alternative Wage Paths}

We use the model to predict what would have happened under alternative scenarios. Therefore, we calculate the labor costs under (i) self-sufficient bargaining and (ii) $5 \%$ lower firing costs and replacement rates in addition. To do so, we assume that the replacement rate is $60 \%$, the firing costs are $60 \%$ and the hiring costs are $10 \%$ of labor costs.

Therefore, we calculate the bargaining parameter $\hat{\mu}_{t}$ for West Germany

$$
\begin{gathered}
\hat{w}_{t}=\left(1-\hat{\mu}_{t}\right) \hat{b}_{t}+\hat{\mu}_{t}\left(\hat{a}_{t}+\hat{f}_{t}\right) \\
\hat{\mu}_{t}=\frac{\hat{w}_{t}(1-\beta)}{\hat{a}_{t}+f_{t}-\beta \hat{w}_{t}}
\end{gathered}
$$

Assuming that East Germans would have the same bargaining parameter as their West German counterparts $\left(\mu_{t}=\hat{\mu}_{t}\right)$, we estimate the East German wage under self-sufficient bargaining:

$$
\begin{aligned}
w_{t} & =\left(1-\hat{\mu}_{t}\right) \beta w_{t}+\hat{\mu}\left(a_{t}+f_{t}\right) \\
w_{t} & =\frac{\hat{\mu}_{t} a_{t}}{1-\left(1-\hat{\mu}_{t}\right) \beta-\hat{\mu}_{t} d}
\end{aligned}
$$

where $d$ is the dependence of the firing costs on the wage level, which was set to $60 \%$.

Using the above formula, we calculate the presumable labor costs under selfsufficient bargaining from 1991 to 2004 . We do the same for a $5 \%$ lower replacement rate and $5 \%$ lower firing costs: $f_{t, \text { new }}=0.95 f_{t, \text { old }}$ and $\beta_{t, \text { new }}=0,95 \beta_{t, \text { old }}$. Next, we use these wage numbers to predict the alternative employment paths. 


\subsubsection{Policy Exercise with Lower Firing Costs and Replacement Ratio}

For the policy exercise with lower firing costs and a lower replacement ratio, we need to know the infinite firing rate to be able to calculate the expected present value of a worker in 2004.

In 2005 a worker is fired if:

$$
\alpha^{15} \varepsilon_{t}>\frac{\alpha(a-w)}{1-\delta \alpha(1-\phi)}+\frac{\alpha(1-\delta) f}{1-\delta \alpha(1-\phi)}
$$

We know that $\varepsilon$ and all other variables are trending at a rate $\alpha$ until infinity. Thus long-run firing rate is equal to

$$
\phi=1-\Gamma\left(\frac{1}{\alpha^{14}} \frac{(a-w)+(1-\delta) f}{1-\delta \alpha(1-\phi)}\right)
$$

We linearize it with respect to all variables to determine its value in the new equilibrium:

$$
\begin{aligned}
\phi_{\text {new }}= & \phi_{0}-\frac{1}{\alpha^{14}} \Gamma_{0}^{\prime}\left[\frac{1}{1-\alpha \delta(1-\phi)}\right]_{0}\left[\left(a_{\text {new }}-w_{\text {new }}\right)-\left(a_{0}-w_{0}\right)\right] \\
& -\frac{1}{\alpha^{14}} \Gamma_{0}^{\prime}\left[\frac{1-\delta}{1-\delta \alpha(1-\phi)}\right]_{0}\left(f_{\text {new }}-f_{0}\right) \\
& -\frac{1}{\alpha^{14}} \Gamma_{0}^{\prime}\left[\frac{-\delta \alpha[(a-w)+(1-\delta) f]}{(1-\delta \alpha(1-\phi))^{2}}\right]_{0}\left(\phi_{\text {new }}-\phi_{0}\right)
\end{aligned}
$$

where variables denoted with new are the infinite values under the alternative scenario.

Thus:

$$
\begin{aligned}
\phi_{\text {new }}= & \phi_{0}-\frac{1}{1-\frac{1}{\alpha^{14}} \Gamma^{\prime}\left[\frac{\delta \alpha[(a-w)+(1-\delta) f]}{(1-\delta \alpha(1-\phi))^{2}}\right]_{0}} \\
& {\left[\begin{array}{c}
\frac{1}{\alpha^{14}} \Gamma^{\prime}\left[\frac{1}{1-\delta \alpha(1-\phi)}\right]_{0}\left[\left(a_{\text {new }}-w_{\text {new }}\right)-\left(a_{0}-w_{0}\right)\right] \\
+\frac{1}{\alpha^{14}} \Gamma^{\prime}\left[\frac{1-\delta}{1-\delta \alpha(1-\phi)}\right]_{0}\left(f_{\text {new }}-f_{0}\right)
\end{array}\right] }
\end{aligned}
$$

The same linearization is performed for the infinite hiring rate, which will be needed later on for the calculation of the expected future wage income stream of a worker.

$$
\eta=\Gamma\left(\frac{1}{\alpha^{14}} \frac{(a-w)-\delta \phi f}{1-\alpha \delta(1-\phi)}-\frac{1}{\alpha^{14}} h\right)
$$

When linearizing, we obtain: 


$$
\begin{aligned}
\eta_{0}= & \eta_{0}+\Gamma_{0}^{\prime}\left[\frac{1}{\alpha^{14}} \frac{1}{1-\delta \alpha(1-\phi)}\right]_{0}\left[\left(a_{\text {new }}-w_{\text {new }}\right)-\left(a_{0}-w_{0}\right)\right] \\
- & \Gamma_{0}^{\prime}\left[\frac{1}{\alpha^{14}} \frac{\delta \phi}{1-\delta \alpha(1-\phi)}\right]_{0}\left(f_{\text {new }}-f_{0}\right)-\Gamma_{0}^{\prime} \frac{1}{\alpha^{14}}{ }_{0}\left(h_{\text {new }}-h_{\text {old }}\right) \\
- & \Gamma_{0}^{\prime}\left[\frac{1}{\alpha^{14}} \frac{-\delta f(1-\alpha \delta(1-\phi))-\alpha \delta[(a-w)-\delta \phi f]}{(1-\delta \alpha(1-\phi))^{2}}\right]_{0}\left(\phi_{\text {new }}-\phi_{0}\right)
\end{aligned}
$$

\subsubsection{Migration}

Infinite Problem: When all variables are trending along the $2 \%$ path (from 2004 onwards for all policy exercises, from 2014 onwards for the prediction), the present value of the future wage income does so too. An insider can either be fired $\phi$, or retained $1-\phi$. The outsider is either hired $(\eta)$, or stays unemployed $(1-\eta)$. Thus the present value of an insider is:

$$
\bar{V}_{i}=w+\delta\left((1-\phi) \alpha \bar{V}_{i}+\phi \alpha \bar{V}_{o}\right)
$$

The present value of an outsider is

$$
\bar{V}_{o}=b+\delta\left(\eta \alpha \bar{V}_{i}+(1-\eta) \alpha \bar{V}_{o}\right)
$$

Thus:

$$
\begin{gathered}
\bar{V}_{o}=\frac{b+\delta \eta \alpha \bar{V}_{i}}{(1-\delta(1-\eta) \alpha)} \\
\bar{V}_{i}=\left(w+\delta \phi \alpha \frac{b}{(1-\delta(1-\eta) \alpha)}\right) /\left(1-\delta(1-\phi) \alpha-\frac{\delta^{2} \alpha^{2} \phi \eta}{(1-\delta(1-\eta) \alpha)}\right)
\end{gathered}
$$

Finite Time Horizon From 1991 to 2004 (and to 2014 for the first prediction) the problem is solved recursively. ${ }^{50}$ The present value of an insider in 1991 is

$$
V_{i, t}=w_{t}+\delta\left(\left(1-\phi_{t+1}\right) V_{i, t+1}+\phi_{t+1} V_{o, t+1}\right)
$$

while it is

$$
V_{o, t}=b_{t}+\delta\left(\eta_{t+1} V_{i, t+1}+\left(1-\eta_{t+1}\right) V_{o, t+1}\right)
$$

for an outsider.

\footnotetext{
${ }^{50}$ We choose this functional form of the insiders' and outsiders' present value for analytical simplicity, but without loss of generality. In combination with (4) it means that East-West migrants are unemployed for one period. Dropping this assumption and changing the sequencing does not affect the results qualitatively.
} 
Estimating Migration and Exogenous Labor Force Growth The labor force (employed plus unemployed) in East Germany is about $50 \%$ of the population. ${ }^{51}$ To generate the effect of migration on the workforce $\left(m_{t}=M_{t-1} / L_{t-1}\right)$ we multiply the actual net migration by 0.5 and divide it by the labor force, assuming that migration in period $t$ affects the labor force growth from $t$ to $t+1$.

The available migration numbers include East Berlin until 2001 and entire Berlin from 2001 onwards (see Statistisches Bundesamt, 2005, p. 52). Since our labor force, productivity, and labor cost numbers do not include Berlin, we corrected the number of migrants by the factor 0.9 before 2001 and by the factor 0.8 after $2002 .{ }^{52}$ To provide an example: 359,126 net migrants in 1990 were multiplied by 0.5 and the correction factor 0.9. The corresponding number was then divided by the labor force in East Germany in 1990 (about 8.6 million). Thus migration reduced the labor force by $-1.8 \%\left(m_{t}\right)$ from 1990 to $1991 .{ }^{53}$

The growth of the labor force cannot be entirely explained by migration, since other factors such as population growth, active labor market policies or early retirement schemes played a very important role (see e.g. Fuchs and Weber, 2005, or DIW Berlin et al., 2002), which cannot be captured by our model. Thus, we define an exogenous residual $g_{t, x}=g_{t, o}-m_{t, m}$.

For the calibration we have to modify equation (4) slightly. To ensure stationarity we assume that the migration costs of the marginal migrant $\kappa\left(m_{j t}\right), j=i, o$ grow at the same rate as the operating costs of the firm and all other variables during the steady state. Thus migration is $m_{j, t}=\kappa^{-1}\left(\frac{K_{j}}{\alpha^{t}}\right)$ and we obtain.

$$
m_{t}=g_{t}-1=\kappa^{-1}\left(\frac{\widehat{V}_{o, t}-V_{i, t}}{\alpha^{t}}\right)+\kappa^{-1}\left(\frac{\widehat{V}_{o, t}-V_{o, t}}{\alpha^{t}}\right)
$$

In a next step, we estimate the equation $m_{t, m}=\beta_{1}+\beta_{2}\left[\left(2 \widehat{V}_{o, t}-V_{i, t}-V_{o, t}\right) / \alpha^{t}\right] 54$ to determine an as good as possible fit between our prediction and the actual values. ${ }^{55}$ We use the estimated coefficients $\tilde{\beta}_{1}$ and $\tilde{\beta}_{2}$ to obtain $\tilde{m}_{t, m}$ for different policy

\footnotetext{
${ }^{51}$ Source: "GENESIS-Online - Das statistische Informationssystem," Statistisches Bundesamt (2005).

${ }^{52}$ In proportion to the respective population shares.

${ }^{53}$ For 1990 we do not have official numbers on the size of the labor force from the Bundesagentur für Arbeit (since unificiation took place in October). Thus, we calculate the growth rate for 1990 and 1991 from DIW (1993, p. 256) and DIW (1994, p. 731).

${ }^{54}$ We do not model West Germany explicitly. To calculate the expected present value of a worker who migrates there, we assume constant firing (8\%) and hiring rates (72\%), see Wilke (2004). Furthermore, we assume that all variables are trending along a 1.5\% trend in West Germany until East Germany has converged to the West German level. Afterwards West Germany's (without the burden of transfer payments, which are currently running at $4 \%$ of GDP) variables continue to grow at $2 \%$ as well. For the years from 1991 to 2004 we use the actual labor cost numbers from Statistische Ämter des Bundes und der Länder (2005).

${ }^{55}$ Therefore, we use ordinary least squares which minimize the squared deviation of the actual from the predicted values.
} 


\begin{tabular}{|l|c|c|c|c|c|}
\hline & Estimated Coefficients & Standard Error & t-Statistics & p-Value & R Square \\
\hline beta 1 & 0.04 & 0.01 & 2.63 & 0.02 & 0.42 \\
\hline beta 2 & $-8.7^{*} 10^{\wedge}-8$ & 0.00 & -2.96 & 0.01 & \\
\hline
\end{tabular}

Figure 10: Estimation of migration coefficients. Dependent variable: $m_{t}$.

exercises, which is the estimated effect of migration on the labor force growth. See figure (10) for the estimated coefficients. ${ }^{56}$

Consequently, the labor force growth rate under different policy exercises is calculated as $g_{t, o}=\tilde{m}_{t, m}+g_{t, x}$, where only the estimated migration effects varies and the exogenous component stays constant.

Employment Dynamics Curve The calculated hiring and hiring rates and the labor market growth are then plugged into the employment dynamics curve:

$$
n_{t}=\frac{1}{g_{t, o}}\left(\eta_{t}+\left(1-\eta_{t}-\phi_{t}\right) n_{t-1}\right) .
$$

\footnotetext{
${ }^{56}$ In this estimation net East-West migration is marked with a negative sign.
} 